No. $19-13$

\title{
Accounting for Racial Wealth Disparities in the United States
}

\section{Jeffrey P. Thompson and Gustavo A. Suarez}

\begin{abstract}
:
Using data from the Survey of Consumer Finances, this paper updates and extends previous research on the racial wealth gap in the United States. We explore several hypotheses that help explain differential wealth accumulation by racial groups, including the importance of receiving inheritances and other financial support from relatives and the conditions in local real estate markets. By exploring the disparities among white, black, and Hispanic families, we make new contributions to the literature. We find that observable factors account for the entire wealth gap between white and Hispanic families and most of the gap between white and black families. Differences in human capital, demographics, and family financial support each make substantial contributions to the wealth gaps we observe between white and nonwhite families. Yet a substantial portion of the wealth gap between white and black families remains unaccounted for after a detailed decomposition. This unexplained portion is greater at the top of the wealth distribution.
\end{abstract}

Keywords: racial wealth gap, inequality, inheritance, savings

\section{JEL Classifications: D31, D63}

Jeffrey P. Thompson is a senior economist and policy advisor in the research department at the Federal Reserve Bank of Boston, where he also serves as the director of the New England Public Policy Center. His email address is jeffrey.thompson@bos.frb.org. Gustavo A. Suarez is the chief of the capital markets section in the division of research and statistics at the Board of Governors of the Federal Reserve System. His email address is gustavo.a.suarez@,frb.gov.

We thank Suchit Mehrotra and Sebastian Devlin-Foltz for excellent research assistance. For helpful comments, we thank Karen Pence, Raven Saks Molloy, Jesse Bricker, Byron Lutz, and participants at the session entitled "Perspectives on Inequality, Mobility, and Wealth," held at the 2015 American Economic Association meeting.

This paper presents preliminary analysis and results intended to stimulate discussion and critical comment. The views expressed herein are those of the authors and do not indicate concurrence by the Federal Reserve Bank of Boston, the principals of the Board of Governors, or the Federal Reserve System.

This paper, which may be revised, is available on the web site of the Federal Reserve Bank of Boston at http://www.bostonfed.org/economic/wp/aspx.

This version: December, 2019

https://doi.org/10.29412/res.wp.2019.13 


\section{Introduction}

While there have always been substantial differences in the wealth accumulated by the white, black, and Hispanic families living in the United States, these differences had remained relatively constant over most of the last three decades, then rose sharply during the Great Recession. The greater losses in net worth that nonwhite families experienced between 2007 and 2010 has inspired renewed interest in understanding the factors that drive these enduring racial wealth disparities. This paper uses data from the Federal Reserve Board's Survey of Consumer Finances (SCF) to update and extend the existing literature, and explores the key factors contributing to the wealth gap that persists among white, black, and Hispanic families.

Our analysis of household wealth data confirms a number of well-established patterns: wealth rises with age up to the point of retirement, and net worth is greater among those families with higher levels of education, income, and inherited wealth. ${ }^{1}$ Wealth accumulation is also greater for families in which the household heads are more tolerant of taking financial risks and have longer-term horizons for saving and investing. The SCF results also show that white families, relative to their black and Hispanic counterparts, are older and more highly educated, have higher incomes and longer work histories, receive larger inheritances, are more likely to receive other types of financial assistance from relatives, tend to report a greater tolerance for financial risk, and have longer investment horizons.

Using linear and nonparametric decomposition techniques, as well as simple reduced-form regressions, we control for each of the factors mentioned above, as well as for additional demographic, labor force, and other related variables, to answer several questions about racial wealth disparities in the United States. We estimate how much of the wealth gap remains "unexplained" once we account for the full range of observable controls present in the SCF. We measure this "unexplained" portion of the wealth gap for the average US family and across the wealth distribution. In addition to analyzing the white/black wealth gap, we also explore the lessstudied wealth differences between Hispanic and white families. Finally, we evaluate the roles that the different factors play in contributing to the wealth gap.

\footnotetext{
${ }^{1}$ Among other sources for basic facts and theories about family savings and wealth, see Diamond and Hausman (1984) and Browning and Lusardi (1996). See Dettling et al. (2017) and Thompson and Suarez (2015) for reviews of the racial wealth gap using descriptive statistics from the SCF.
} 
Differences in human capital—reflected in direct measures of educational attainment, as well as variables for earned income, occupation, years of full-time work, and attitudes toward saving and investing - appear to be the most important set of factors explaining the racial wealth gap, as these human capital differences account for between one-third to two-fifths of the explained portion of the racial wealth gap in the United States. ${ }^{2}$ Demographic differences and family financial support measures each contribute to explaining between one-fifth and one-third of the racial wealth gap. Our analysis is able to account for a greater share of the observed average whiteblack wealth gap than most previous research (Scholz and Levine 2003). ${ }^{3}$

We find that observable factors account for essentially all of the differences that exist between white and Hispanic families at the mean of the wealth distribution. These same factorsnot including homeownership - also account for between 69 and 89 percent of the mean wealth difference between white and black families, but a substantial portion of the disparity remains unexplained. Controlling for homeownership - even though it is better regarded as an outcome of, rather than a driver of racial differences - further increases the amount of the wealth gap that we can account for at the middle of the distribution; at the median, the portion of the gap between whites and nonwhites that can explained by observable factors rises between 9 and 13 percentage points when an indicator for homeownership is included. After controlling for all of these factors, the average white family has a net worth that is nearly twice as large as the wealth accumulated by the average black family. We also show that all of the mean wealth difference among white and black families is due to differences in assets, as the differences in debt shrink to zero once the full range of observable characteristics are included. Hispanic families, on the other hand, hold considerably less debt and only modestly greater assets compared to black families. ${ }^{4}$

Observable factors are less able to explain racial wealth disparities at the top of the wealth distribution. Among the wealthiest 10 percent of families, for example, observable factors can only account for 61 percent or less of the gap between white and black families and 80 percent or

\footnotetext{
${ }^{2}$ The coefficients on homeownership are as large as—or larger than — any other single variable, but the homeownership variable is not regarded as a plausible causal factor in the same way as the other variables. The inclusion of the homeownership variable primarily reflects how important this particular asset class is in ameliorating or facilitating the racial wealth gap.

${ }^{3}$ Scholz and Levine (2003, p. 10) find that "[w] hen coefficients estimated from a sample of blacks are used to predict white wealth, estimates [of the explained portion of the racial wealth gap] range between 12 and 84 percent, with most falling between 20 and 35 percent."

${ }^{4}$ In the initial OLS regressions, black is the excluded group for ease of interpretation. None of the results from the OLS regressions change if white is the excluded group.
} 
less of the gap between white and Hispanic families. At the bottom of the wealth distribution, differences in observable factors can completely account for the observed white/Hispanic and white/black wealth gaps, in the sense that we can roughly predict the wealth of one group by using its observable characteristics, but then applying the returns on those observable characteristics estimated for the other group.

Although the unexplained portion of the racial wealth gap is sometimes regarded as a proxy for the influence of racial bias, it is important to note that we do not regard it as such. Certainly racism - as represented by the "redlining" practices that limited access to financial services for minorities and lowered homeownership rates among nonwhites, discriminatory hiring practices, and the lingering influence of other past race-driven differentials - accounts for some of the unexplained differences in wealth accumulation among white, black, and Hispanic families. However, the unexplained portion would also include any other unobserved factors influencing racial wealth differences. More importantly, the influence of racial bias on wealth differences is not limited to the unexplained component in the wealth regressions.

Some of the key observable factors that account for the wealth gap in our analysis may also reflect the influence of racial bias. Educational attainment, for example, could differ systematically across racial groups based on the quality of locally-provided education. Incomes are not perfectly explained by educational attainment, and could be influenced by biased hiring practices and other forms of racial discrimination. ${ }^{5}$ There is also a rich literature documenting how racial discrimination — past and present—helps explain lower rates of homeownership and home equity accumulation among black and Hispanic families (Charles and Hurst (2002), Sharp and Hall (2014), and Bayer, Ferreira, and Ross (2018)). Ultimately, the decomposition analysis provides an accounting of the relative contributions of the factors that are the proximate drivers - if not necessarily the underlying causal factors - of the wealth differences between white and nonwhite families.

The remainder of the paper is organized as follows. Section 2 introduces the SCF data used in the analysis, while section 3 describes the differences in net worth among white, black, and Hispanic families in our data (the "naïve" wealth gap) and documents how those differences have evolved over the last three decades. Section 4 discusses the primary factors that shape the wealth-accumulation process and uses reduced-form OLS regressions to assess the importance of 
those observable variables in accounting for the racial wealth gap. In section 5 we use OaxacaBlinder decompositions and nonparametric decompositions, following the approaches used in Barsky et al. (2002) and DiNardo, Fortin, and Lemieux (1996), to assess how much of the naïve racial wealth gap can be accounted for by these observable characteristics and to describe the relative contributions of the different factors. The final section concludes.

\section{The Survey of Consumer Finances}

We use data from the ten waves of the Federal Reserve Board's triennial Survey of Consumer Finances (SCF), conducted between 1989 and 2016. Several features of the SCF make it appropriate for analyzing the factors that contribute to racial wealth disparities. The survey collects detailed information about families' financial assets and liabilities, and has employed a consistent design and sample frame since 1989. As a survey of household finances and wealth, the SCF includes some assets that are broadly shared across the US population (bank savings accounts) as well some that are held more narrowly and that are concentrated in the upper tail of the wealth distribution (direct ownership of bonds).

To support making estimates of a variety of financial characteristics as well as the overall distribution of wealth, the SCF employs a dual-frame sample design. A national area-probability sample provides good coverage of widely shared characteristics. The SCF also employs a list sample of households with a high probability of having high net worth, which is developed from statistical records derived from tax returns. ${ }^{6}$ Observations from the national area-probability sample and list sample are joined through weighting. ${ }^{7}$ Then these combined weights are used in all regressions.

The key outcome variables explored in this paper are net worth, total assets, and total debt. Total assets include the value of all financial and nonfinancial assets, including residential and nonresidential real estate and ownership interests in any businesses, reported by the respondent at

\footnotetext{
${ }^{6}$ See Bricker et al. (2017) and Bricker et al. (2016) for recent discussions of the sampling strategy, the list sample, and the weights used in the SCF. See Wilson and Smith (1984) for a description of the Statistics of Income file. The file used for each survey largely contains data from tax returns filed for the tax year two years before the year the survey takes place.

${ }^{7}$ The SCF weights were revised in 1998 to incorporate homeownership rates by race (Kennickel 1999). Weights for earlier years were updated to reflect the revised methodology.
} 
the time of the interview. ${ }^{8}$ Total debt reflects all types of debt, including credit cards, mortgage debt, student loans, business debts, and other miscellaneous forms of debt.

Respondents are also asked about their income, including income from wages as well as the family's "usual" income in a "normal" year. The "usual income" classifier is designed to capture a version of family income with transitory fluctuations smoothed away (Bricker et al. 2017). Usual income differs from actual income when the respondent reports that the family experienced a negative or positive income "shock" that is transitory in nature, say from a temporary unemployment spell or an unexpected salary bonus. A series of questions on work history allow us to measure the number of years of full-time work over a respondent's lifetime.

In addition to collecting data about a family's finances, the SCF also collects some basic demographic information, primarily pertaining to the family head. The survey records the family head's self-identified race, chosen from among seven options. The exact wording of the telephone version of the survey is as follows: "Which of these categories do you feel best describe you: white, black or African American, Hispanic or Latino, Asian, American Indian or Alaska Native, Hawaiian Native or other Pacific Islander, or another race?” Prior to 1998, respondents were only allowed to choose a single category. Starting in 1998 respondents were allowed to give multiple responses, but first they were asked to indicate the category that they identified with most strongly. The variable in the public version of the SCF is based on the first answer provided. Very few people give more than one response. Beginning in 2004, respondents, regardless of race, were also asked a question to determine whether their cultural origins were Hispanic or Latino.

In most of the following analysis, we use the race variable for the respondent that reflects the first option chosen in the 1998 SCF and all the following surveys, in order to avoid any complications potentially related to the changes in the race variable in 1998 (allowing for the selection of multiple races) and in 2004 (allowing for the separate identification of Hispanic ethnicity). ${ }^{9}$ Over the 2001-2016 period, which is the focus of most of the analysis, of the family heads surveyed in the SCF, 72 percent were white, 14 percent were black, and 10 percent were Hispanic (Table 1). Of the remaining 4 percent of the families included in the survey, the single

\footnotetext{
${ }^{8}$ Assets do not include, and the SCF does not collect information on, the value of a respondent's defined benefit pensions or the implied annuity value of future or current Social Security benefits.

${ }^{9}$ The wealth numbers here will differ somewhat from Dettling et al. (2017), which focuses on recent years and identifies "white" families as those headed by respondents self-identifying as white, non-Hispanic only; "black" as those who identify as black or African American, non Hispanic only, and "Hispanic" as those identifying as Hispanic only. Later we show that these different definitions are not important for the decomposition analysis.
} 
largest group was Asian. In part of the regression analysis that appears later in the paper, we conduct some sensitivity analysis and explore whether the observed correlations between race and wealth change when we modify the racial categories using the addition of the Hispanic ethnicity variable in 2004.

In the SCF, the unit of analysis is the "primary economic unit" (PEU), which refers to a financially-dependent group of individuals (related by blood, marriage, or an unmarried partnership) living together. This concept of a PEU is distinct from the household or family unit definitions employed by the Census Bureau, though conceptually the PEU is closer to the latter. Thus, throughout this paper, PEUs are referred to as "families." 10 Single individuals living alone are included and simply considered to be a "family" consisting of one member

\section{Wealth by Race in the Survey of Consumer Finances}

The responses to the SCF indicate that the differences in net worth between white, black, and Hispanic families are substantial and long-standing. For most of the last three decades, the average net worth of white families was between five and six times greater than the average net worth of black families, and white families had between four and five times more wealth as that held by Hispanic families (Table2, Panel A). Between 2007 and 2013, the wealth gap rose sharply: by 2013 , the average wealth of white families was seven times greater than that of black families and six times greater than that of Hispanic families. Between 2013 and 2016, nonwhite families saw proportionally larger increases in wealth — by 2016, the average net wealth of white families fell back to being 6.5 times as large as that of black families and five times as large as Hispanic families. In absolute terms, the wealth differences between these three racial groups are very large. In 2016, the mean net worth of white families was $\$ 904,000$, compared to mean net worth of $\$ 140,000$ for black families, and $\$ 182,000$ for Hispanic families.

Median net worth levels are substantially lower than mean levels for all racial groups, a finding which is not surprising, since wealth is known to be highly concentrated at the top of the distribution (Bricker et al. 2017). Median net worth in 2016, for example, was $\$ 163,000$ for white families, \$16,600 for black families, and \$21,500 for Hispanic families (Table 2, Panel B). Wealth

\footnotetext{
${ }^{10}$ A typical question in the SCF asks the respondent to consider "you and your family living here" when providing answers.
} 
is lower at the median of the distribution than at the mean, but the relative differences between the races are actually larger at the median; for every survey year, the relative wealth of white families is higher when using median net worth than when using mean net worth and using black or Hispanic families as the reference group. ${ }^{11}$

Following the 2008-2009 recession, mean and median wealth declined for families of all races. Between 2007 and 2010, the mean net worth of white families fell from $\$ 783,000$ to $\$ 702,000$, and their median net worth fell from $\$ 189,000$ to $\$ 137,000$. Mean and median net worth also declined for nonwhite families between 2007 and 2010, but it continued to fall between 2010 and 2013, while the wealth of white families started to recover. Between 2013 and 2016, the median and mean net worth rose for all racial groups. Median wealth for black families rose from $\$ 11,400$ in 2013 to $\$ 16,600$ in 2016 , and for Hispanic families it rose from $\$ 14,200$ to $\$ 21,500$.

Table 1 provides more detail regarding the absolute and relative levels of assets and debt for white, black, and Hispanic families for each year the SCF was conducted between 1989 and 2016. Mean assets in 2016 were $\$ 1$ million for white families, $\$ 196,100$ for black families, and $\$ 247,000$ for Hispanic families. These differences in assets are greater than the differences in debt. In particular, while white families had mean assets that were roughly five times as great as those held by nonwhite families, the mean debt levels of white families were only double the amount of their nonwhite counterparts.

The sample sizes in the SCF are large enough to allow us to make reliable estimates of statistics such as mean and median net worth, but, as with all measures based on survey data, these estimates do have some sampling error. Taking the 95 percent confidence interval into account confirms that the wealth differences between white and nonwhite families are substantial and persistent (Figure 1A). The white-to-black ratio of mean family wealth was between 4 and 8 in each year from 1989 to 2007, but exhibited no trend. Since 2010 the gap has risen to somewhere between 5 and 11, with a pronounced upward trend.

\footnotetext{
${ }^{11}$ The relative wealth of white families, measured by using median net worth, is particularly high in 1989. This discrepancy is largely due to the especially low measured wealth levels for the typical black and Hispanic families. The increases in median wealth for nonwhite families after 1989 likely reflect both material improvement in their balance sheets and the SCF doing a better job of reaching nonwhite families. In 1989, there were only 308 black families and 162 Hispanic families interviewed in the SCF. By 1992, those numbers had risen to 357 and 217 families, respectively, and have continued to increase since. In the $2016 \mathrm{SCF}, 835$ black families and 612 Hispanic families were interviewed.
} 
Summary measures of the wealth distribution, such as the ratios of the means described above, are also potentially quite sensitive to large changes in the extreme tails of the distribution. White/black ratios that exclude the top and bottom 1 percent of families in the data or that rely on transformations of the data that otherwise moderate the impact of extreme tails - such as the inverse hyperbolic sine - show even more clearly that a flat trend persisted over most of the last three decades followed by a pronounced uptick in recent years (Figure 1B).

\section{Dynamics of Racial Wealth Differences in the Survey of Consumer Finances}

Among the important factors related to the process of accumulating wealth are life-cycle dynamics, human capital development, and the receipt of inheritances and other forms of financial support from relatives. Wealth is accumulated over time, and individuals are able to build wealth as they work, marry, and otherwise pass through different stages of life. People with greater skills and higher earnings are also more easily able to save out of their income. Families who have received inheritances and other financial support from relatives are also able to build wealth more easily than those families who have not benefited from these same advantages. Each of these factors is associated with the accumulation of wealth, and any differences in these factors across racial groups could play an important part in accounting for the wealth gaps described in the previous section. ${ }^{12}$

In fact, the data indicate that these factors differ substantially across racial groups. Compared to their nonwhite counterparts, white families are older, more highly educated, more likely to be married or partnered, have longer full-time work histories, have higher incomes, and are more likely to have attitudes toward saving and planning that are consistent with successful wealth accumulation. White families are also more likely to receive an inheritance, more able to count on substantial financial assistance from other relatives in an emergency, and more apt to expect to receive future inheritances. Table 1 shows summary statistics for white, black, and Hispanic families for each of these variables and a host of others as well.

The net effect of these different factors in accounting for the disparities in wealth between white and nonwhite families is uncertain. No individual factor, on its own, however, is likely to be

\footnotetext{
${ }^{12}$ Scholz and Levine (2003) review the range of the factors influencing the racial wealth gap.
} 
dispositive. The relationship between age and wealth is illustrative. A basic stylized life-cycle pattern of wealth accumulation expects that young people will have low (or negative) wealth, as they have not had time to save and have likely borrowed to build up their human capital. Individuals start to accumulate more wealth as they enter the workforce and their incomes rise. Wealth peaks at the point of retirement, and starts to decline as retirees stop accumulating assets and begin to fund consumption out of their savings. Figure 2 illustrates this standard age pattern using the SCF for 2016. ${ }^{13}$ Mean assets and net worth both rise steadily up to the point of retirement, peak (at $\$ 1.3$ to $\$ 1.4$ million) at age 59 , and decline thereafter. The ratio of mean debt to assets is highest in the late $20 \mathrm{~s}$, a time in life when most students have just completed college or graduate school. Debt grows at a faster rate (by year of age in the cross section) than assets up through the late 20s, at which point growth in assets starts to outstrip that of debt.

The importance of aging for understanding wealth cannot be overstated. We know that in the United States, the white population is older, with a greater portion at their peak earning years and in the early phases of retirement. In the 2016 SCF, the mean age of a family head was 52.2 years for white families, 47.7 years for African Americans, and 43.0 years for Hispanics. Nearly 30 percent of white families are headed by an individual who is 65 years of age and older, compared with 21 percent for black families and 13 percent for Hispanic families.

Age differences alone, however, cannot account for the racial wealth disparities in the United States. Figure 3 shows the age and median net worth profile by race for the SCF conducted in 1989, 2007, 2013, and 2016. The profile for white families depicts the usual pattern of wealth accumulation rising until retirement, followed by decline in wealth as assets are drawn down. The median net worth of white families with heads aged 55 to 64 peaked at $\$ 360,000$ in 2007 and fell over the next two surveys, hitting a low of $\$ 260,000$ in 2013 , before recovering to $\$ 275,000$ in 2016.

Compared to white families, the median wealth of black families is much lower, and the pattern of wealth rising with age up until retirement and then subsequently declining is almost completely absent. For black families in each of the selected survey years, median wealth peaks at age 65 and older. ${ }^{14}$ In contrast, the age and median net worth profiles for Hispanic families do

\footnotetext{
${ }^{13}$ The simple wealth by age profiles in Figure 3 reflects both life cycle and cohort effects.

${ }^{14}$ These deviations from the aggregate age/wealth profile could be accounted for by differences in labor force participation, retirement behavior, and life expectancy, but could also be due to the relatively small
} 
depict a clear pattern of wealth accumulation up to retirement, followed by a decline. At all points of the life cycle, however, Hispanic families (as well as black families) have net worth levels that are substantially lower than those of their white counterparts.

To simultaneously account for the contributions of age, education, income, work history, inheritance, financial support from relatives, skill at investing, and other factors that might generate differential wealth accumulation among racial groups, we employ several different approaches. In the following subsection, we start with simple reduced-form OLS regressions. In section 5, we explore both linear and nonparametric decomposition techniques. In each case we are trying to determine the size of the residual wealth gap that cannot be explained by observable factors, as well as determining the relative contributions that the different observable variables have on wealth disparities.

The goal of this analysis is to decompose the contribution to the racial wage gap of the previously discussed wealth accumulation factors as well as some additional influences. Additional covariates in the regression analysis include: other demographic and family-type measures (number of children living in the family home, number of children living elsewhere, marital status, presence of spouse/partner, and urban/rural indicator); educational attainment of spouse; labor force, industry and occupation indicators; regional real estate variables (MSA-level quality-adjusted rents and one, five, and ten-year county-level house price index growth rates); health status indicators for the respondent and spouse; parental survival and age variables for the respondent and spouse; the number of living siblings for the respondent and spouse; and familylevel indicators for homeownership and stock holding. The summary statistics, by race, for each of these covariates are included in Table 1. Further intuition for including each of these variables is provided below when we discuss their relative contribution to the Oaxaca-Blinder decompositions.

cell sizes in the data. There are, for example, fewer than 150 black families with heads ages 65 and older in the data in 2016. 


\subsection{OLS Results}

The key coefficients obtained from running simple OLS regressions using the SCF data from 2001 through 2016 are reported in Table 3. ${ }^{15}$ Panel A reports the key coefficients obtained from specifications using the inverse hyperbolic sine (IHS) of net worth as the dependent variable, while those in Panels B and C use assets and debt, respectively. The IHS is the preferred transformation of net worth, as it maps negative (positive) values of net worth into negative (positive) values, is defined at zero, and the interpretation of the coefficients is equivalent to that of a natural log. ${ }^{16}$ The key regressors of interest are the indicator variables for the self-identified race of the family head, including "white" and "Hispanic," with the black family head being the excluded category. ${ }^{17}$

The unconditional racial wealth gap is depicted in Panel A, Column 1 of Table 3, which regresses net worth only on the racial indicators and year dummies. With the IHS of net worth regressed on the indicators for white and Hispanic family heads, the key coefficients can be interpreted like semi-elasticities: at the mean, the net worth of white families is 370 percent larger than that of black families, and the net worth of Hispanic families is 112 percent greater than that of black families. Adding the full range of control variables described earlier and shown in Table 2 -excluding income and homeownership — reduces the magnitude of the white coefficient by two-thirds, but has no net effect on the Hispanic coefficient (Column 2). These results suggest that once we control for variables pertaining to demographics, labor force participation, education, health, local real estate market conditions, inheritances and other family financial assistance, the average wealth of white and Hispanic families is twice as large as that of the average black family. The full results for this one specification, showing the coefficients for all control variables, are included in Appendix Table 1.

The remaining columns in Table 3 add successive controls for income and homeownership. Income has received special attention in previous research on the white/black wealth gap; Barsky et al. (2002) focus on the importance of earnings differences for understanding the wealth

\footnotetext{
${ }^{15}$ One key variable reflecting family financial support — whether the respondent could get $\$ 3,000$ from relatives or friends in a financial emergency - is only available beginning with the 2001 SCF.

${ }^{16}$ See Pence (2006) for a discussion of the use of IHS transformations of net worth.

${ }^{17}$ Typically the more numerous group is the one chosen to be excluded (white in this case). To make it easier to interpret the coefficients, here we are using black as the excluded group. The regression results presented in Table 3 are unchanged whether the excluded group is white or black. Each of the regressions also uses only one imputation of the data.
} 
gap, while Altonji and Doraszelski (2005) argue that lifetime income is the more appropriate metric for understanding group differences in net worth. As anticipated, the variable for "usual income," which is less subject to short-term transitory fluctuations than either actual income or earnings, is closely related to wealth (Columns 3 ). Including a control for usual income leads to a 20 percent decline in the coefficient for a white family head, compared to a 1 percent decline after controlling for earnings. There is no change, however, in the indicator for an Hispanic family head. Controlling for usual income, we see that the wealth of the average white family is 92 percent larger than the wealth of the average black family; the wealth of the average Hispanic family is 114 percent larger than the wealth of the average black family.

Controlling for homeownership results in a dramatic reduction in the coefficient associated with being white, but has a more modest impact on the coefficient associated with being Hispanic (Column 4). The coefficient on homeownership is very large itself: the average net worth for homeowners is more than 400 percent higher than for those families not owning homes, conditional on controlling for all of the other factors. Controlling for homeownership reduces the coefficient on being white by 47 percent (comparing Column 4 and Column 2). By itself, homeownership is, of course, correlated with race. Using these same variables to estimate a linear probability model for homeownership, we find that white families are 10.2 percent more likely to own their home than are black families, while Hispanic families are 1.4 percent more likely to own their own home compared to black families. Whatever other unidentified factors are influencing racial differences in homeownership (or educational attainment for that matter) are also influencing wealth accumulation. Including an indicator for homeownership as an independent variable in our wealth regressions is one way to help us understand how portfolio composition or access to mortgage financing influences the wealth gap.

Once usual income and homeownership are both included, wealth for the average white family is now "only" 48 percent larger than that of the average black family (Column 5). ${ }^{18}$ The wealth differential between Hispanic and black families, though, is hardly affected; the wealth of the average Hispanic family is 90 percent higher than the wealth of the average black family, once we control for homeownership and usual income.

\footnotetext{
${ }^{18}$ An additional control for stockholding is positively related to wealth, but its inclusion has no impact on the racial wealth gap, so it is not included here.
} 


\section{Using Assets and Debt as the Dependent Variable}

A family's net worth is defined as the total value of its assets less the total amount of its debts, and the observed differences in the racial wealth gap could be driven by either assets, debt, or both. Panels B and C in Table 3 report the key coefficients obtained from running the same OLS specifications, but instead of net worth, these specifications use assets (IHS) and debt (IHS) as the dependent variables. The regression results from this exercise indicate that the white-black wealth gap, conditional on including a covariate for homeownership, is almost entirely due to differences in asset accumulation. The wealth gap that exists between Hispanic and black families is more evenly split by differences in assets and debt, but is mostly due to Hispanic families having less debt than black families.

The specification in Table 3, Column 2, conditional on the full range of control variables, excluding income and homeownership, indicates that the average white family has 77 percent more assets compared to the average black family (Panel B, Column 2). The average white family has 47 percent more debt than does the average black family (Panel C, Column 2). Including usual income and homeownership (Column 6) reduces the coefficient on the white indicator in the assets regression to .32 , and reduces the coefficient on the white indicator in the debt regression to -.11.

Differences in assets and debts account for roughly two-thirds and one-third, respectively, of the wealth gap that exists between Hispanic and black families. The Hispanic coefficient is .41 in the asset model (Panel B, Column 2) and is -.31 in the debt model (Panel C, Column 2). Controlling for income and homeownership has a more modest impact on the Hispanic coefficients, lowering the asset model coefficient to .27 and raising the absolute value of the debt model coefficient to -.57 .

\section{Decomposing the Wealth Gap: Oaxaca-Blinder and DiNardo, Fortin, and Lemieux}

Below we provide the key results obtained from performing a series of decompositions, then break down the observed differences for the racial wealth gap into components that are accounted for by the observed covariates and by an unexplained portion. ${ }^{19} \mathrm{We}$ first use the use

\footnotetext{
${ }^{19}$ This basic approach was developed by Oaxaca (1973) and Blinder (1973). We estimate the decompositions in STATA using the routine developed by Jann (2008).
} 
the standard Oaxaca-Blinder (O-B) method and then employ nonparametric decomposition techniques developed by DiNardo, Fortin, and Lemieux (1996) and Barsky et al. (2002).

The O-B decomposition assumes that a linear relationship exists between the dependent and independent variables, and the method is based on separately identifying the contribution of differences in observed traits among groups (such as educational attainment) and the differences in the returns to those traits (such as returns to education). Separate regressions are run for two groups, and the regression coefficients for one group are applied to the covariates of the other group to obtain the counterfactual analysis (e.g., what would black family wealth look like if the traits of black families enjoyed the same "return" as that of white families.)

The basic O-B decomposition is limited by its underlying assumption that the wealth function is linear. As Barsky et al. (2002) argue, there are good reasons to think the wealth function is not linear in terms of income (or in terms of any number of additional explanatory factors), and there is little reason to think that we know the actual functional form. The standard O-B decomposition can also be sensitive to the choice of the excluded group, potentially giving different answers for the "unexplained portion." This sensitivity is partly related to a lack of common support in the distributions of the groups being compared. In the case of the wealth and income distributions, there are portions where the white, black, and Hispanic distributions do not overlap (Appendix Figures 1A, 1B). In these cases, the O-B predictions extrapolate beyond the observed income and wealth range for black families.

An alternative decomposition approach that addresses these concerns about the O-B method is the DiNardo, Fortin, and Lemieux (DFL) (1996) reweighting estimator. The DFL uses a nonparametric approach, does not assume a linear wealth function, and also assigns a zero (or near zero) weight to observations that lack common support. The DFL estimator can also easily be used to decompose differences across the distribution, not simply at the mean, as is the case in the standard O-B decomposition.

Conceptually, the DFL estimator is simple: it reweights data from one group to give it the same composition of traits as observed in another group. ${ }^{20}$ When the skills, income, and other traits of the various groups in the SCF samples are compared, the estimated counterfactual becomes "what would the density of wealth have been among white families if they had the skills,

\footnotetext{
${ }^{20}$ Originally the DLF estimator was used to reweight over time. Here, and in Barsky et al. (2002), the DFL estimator is used to reweight different groups in the same period.
} 
income, and other traits of black families (but retained their own wealth function)?" The outcome of interest (here, wealth) and the regressors (here, skills, income and other traits) are assumed to have a joint distribution, so that as the regressors are observed more frequently, so will the outcomes be observed more frequently. Importantly, no parametric assumptions are placed on the formation of these outcomes and the estimator allows inferences to be drawn along all points of the distribution of outcomes. The reweighting estimator also forces estimates to be drawn from common supporting evidence across the two samples. ${ }^{21}$

Once the traits of white families have been reweighted so that their distribution of observables (z) matches that of black families, the difference between levels of wealth for white families in the original sample and in the reweighted sample then becomes our measure of the impact that being white has on accumulating wealth, information which helps to explain the racial wealth gap. The reweighting function used is a ratio of propensity scores estimated from probit regressions:

$\Psi(z)=\frac{\operatorname{Pr}(b \mid z)}{\operatorname{Pr}(w \mid z)} \frac{\operatorname{Pr}(w)}{\operatorname{Pr}(b)}$.

As noted by DiNardo (2002) and Fortin, Lemieux, and Firpo (2011), this reweighting by a (ratio of) propensity scores confers the same benefits as those obtained from propensity score matching using the method in Rosenbaum and Rubin (1983). The weight $(\psi(z))$ allows us to collapse a multidimensional integration problem (i.e. integration over each component of $z$ ) into a onedimensional integration problem.

\subsection{A. Oaxaca-Blinder Results}

Panel A in Table 4 contains the basic O-B decomposition results for the white/black (Columns 1-3) and white/Hispanic (Columns 4-6) wealth gaps for the three main specifications. Here, the decomposition applies the coefficients from the wealth equation estimated on white families to black (Hispanic) families. We note that in this case, the results do not change

\footnotetext{
${ }^{21}$ Both observable and unobservable variables determine the outcome. The method assumes that the density of an outcome, conditional on the inputs and the density of the inputs, are independent. The inputs are reweighted while the conditional density remains unchanged, so the estimates only rely on changes in the observables, while the distribution of unobservable variables remains unchanged. Unobservables may possibly play a large role in determining wealth outcomes. It is assumed here that the effect of unobserved variables is the same across groups.
} 
appreciably if the black (Hispanic) coefficients are applied to white families. Including all of the covariates except for income and homeownership (equivalent to Column 2 in Table 3), group differences in a broad range of observable traits account for 63 percent of the difference in net worth between black and white families (Column 1). When we include usual income, the portion of the gap that we can account for rises to 69 percent (Column 2), and adding an indicator for homeownership raises it to 82 percent (Column 3). Equivalent decompositions reported in Columns 4-6 account for 92, 100, and 111 percent, respectively, of the white/Hispanic wealth gap. When white families are given the same returns to observable traits as Hispanic families, the wealth of the average white family falls below the wealth of the average Hispanic family. These findings are unchanged if we modify the racial definitions to exclude white Hispanics from the "white" category. ${ }^{22}$

\subsection{B. Evaluating the Contributions of Different Factors}

In Panel B of Table 4, we explore the relative contributions of each of the groups of control variables in accounting for the explained portion of the white/black and the white/Hispanic wealth gaps.

\section{Demographics}

Earlier we discussed the relationship between age and wealth, but family composition and size also influence wealth accumulation (Scholz and Seshadri 2007). ${ }^{23}$ Married couples are able to share a residence and other resources-living more cheaply than two single people - and a family with two incomes will be able to generate greater savings than a family with one income. On the other hand, raising children is expensive, and will negatively affect a family's ability to save. These demographic factors are associated with differences in family-level net worth, and

\footnotetext{
${ }^{22}$ These alternative decompositions can only be carried out using data from 2004 and later, since the Hispanic ethnicity question was added to the SCF in 2004.

${ }^{23}$ The demographic variables used in all specifications include age and the square of age for both the respondent and spouse, as well as variables used to reflect the influence of the "nuclear" family as well as the extended family. Nuclear family traits include the number of children living in the family home and a categorical variable for family type, with unmarried family heads with children serving as the excluded family group. Variables reflecting the influence of the extended family and other household conditions include an indicator for the presence of "nonprimary economic unit" (NPEU) members of the family, the number of related children living elsewhere, and a series of variables reflecting the number of siblings that the respondent and spouse have, as well as their parents' ages (an indicator for whether alive and the age) of their parents.
} 
also account for a meaningful portion of the wealth gap found between white and nonwhite families. In the O-B decompositions that do not include either income or homeownership controls, combined demographic factors account for approximately one-third of the explained portion of the wealth gap among white and nonwhite families (Table 4, Columns 1, 4). Age is the most important factor in explaining the white/Hispanic gap, while nuclear family traits (marital status, number of children) are the most important for explaining the white/black wealth gap. Demographic variables account for a smaller, though still important, portion of the total explained wealth gap when we include controls for income (Columns 2, 5) and homeownership (Columns 3, 6).

\section{Human Capital}

Variables measuring earnings capacity and work experience also make an important contribution to the racial wealth gap. When combined, the various human capital controls account for 29 percent of the explained white/black wealth gap and explain 27 percent of the explained portion of the wealth gap that separates white and Hispanic families. ${ }^{24}$ Since we are already controlling for employment status, occupation, industry, and years of full-time work, there appears to be little direct role for educational attainment. Being employed in a managerial or professional occupation and being self-employed or a partner in a business are traits that are positively related to wealth. Each additional year that the respondent spends in full-time employment raises the family's net worth by 3.8 percent (Appendix Table 1). These combined workforce variables account for approximately 15 percent of the explained white/nonwhite wealth gaps. Attitudes toward saving, investing, and borrowing also seem to matter for wealth accumulation. Families that are risk tolerant and those with longer planning horizons have higher net worth, while families that are comfortable with the idea of borrowing money to fund vacations have lower net worth. Attitudinal variables account for approximately 10 percent of the explained wealth gap between white and nonwhite families.

When we include a control for income, the direct contribution of these individual human capital variables decline in turn, as they are all indicators for earning capacity. By itself, income accounts for 28 percent of the explained white/black wealth gap and 24 percent of the

\footnotetext{
${ }^{24}$ The full set of human capital variables used in the decomposition are shown in Table 2 and in Appendix Table 1.
} 
white/Hispanic wealth gap (Columns 2, 5), pushing the combined contribution of human capital factors up to 45 percent and 34 percent, respectively.

\section{Residential Real Estate Markets and Homeownership}

It has been suggested that local real estate market conditions may play an important role in accounting for the racial wealth gap. Residential real estate accounts for a large share of the total wealth of nonwhite families, and low-wealth families are relatively highly leveraged on their real estate holdings. As a result, booms and busts in home prices have a disproportionate effect on lowwealth, highly-leveraged homeowners. Consistent with these dynamics, Wolff (2016) has suggested that differentials in local price trends, combined with leverage ratios, may help explain the particularly sharp decline in black family wealth and the accompanying rise in the white/black wealth gap following the Great Recession. We include one, five, and ten-year changes in regional real estate price indexes, which capture movements in prices at the local level, an important source of heterogeneity given that racial groups are not distributed evenly throughout the country. Specifically, we use the county-level housing price index from CoreLogic. We also use a measure of the regional cost of living (quality-adjusted rent). ${ }^{25}$ The coefficients on the regional real estate variables generally have the anticipated signs in an OLS specification (Appendix Table 1), but their inclusion does not impact the wealth gap between white and nonwhite families. Years of tenure in the current residence (owned or rented), however, account for 7 percent of the white/black wealth gap and 11 percent of the white/Hispanic wealth gap.

Including an indicator for homeownership (Table 4, Columns 3 and 6) soaks up all of the signal from the other real estate variables, as well as much of the signal provided by the human capital and demographic variables. Adding homeownership raises the total explained share of the racial wealth gap by a little more than 10 percentage points, but by itself, the homeownership variable contributes 40 percent of the total explained portion of the white/nonwhite wealth gap.

\footnotetext{
${ }^{25}$ The q-rent (quality-adjusted rent) variable is developed in Chen and Rosenthal (2008). It varies at the MSA-level, and the values used in this specification are for 2000. Chen and Rosenthal construct their cost measure by estimating a hedonic regression controlling for structural characteristics of housing units in each MSA and state non-MSA from the 2000 Census. The estimate reflects renter and owner-occupied housing, and is expressed at an annualized rate, ranging from $\$ 4,300$ to $\$ 24,000$, with a mean of $\$ 7,900$.
} 
We do not regard homeownership is an independent factor in itself, but its inclusion does shed some light on the ways in which the other variables-both the observed controls and the unobserved influences - help drive the differential wealth accumulation of white and nonwhite families.

\section{Financial Support from Relatives}

Intergenerational wealth transfer via an inheritance is one of the most notable means by which familial support can influence wealth accumulation and potentially helps account for the racial wealth gap (Menchik and Jianakoplos 1997). This analysis uses several variables to reflect the influence of receiving an inheritance, including the IHS of the inflation-adjusted value of an inheritance already received, the number of years since the most recent inheritance was received, and indicators for the receipt of a house, other real estate, or a family business. The OLS coefficient on inheritance indicates that a 10 percent increase in inherited wealth, which can be received at any point in the past, raises a family's current net worth by 0.8 percent at the mean (Appendix Table 1). Inheriting a house, other real estate, or a business is associated with increases in net worth of 32 percent, 81 percent, and 116 percent, respectively. These variables are related to wealth accumulation, but, consistent with Altonji and Doraszelski (2005), they have only a modest impact on the explained portion of the racial wealth gap. Inheritances account for 6 percent of the white/black wealth gap and 8 percent of the white/Hispanic wealth gap (Table 4, Columns 2 and 4).

Other forms of financial assistance from relatives turn out to have a much greater impact on the racial wealth gap. The SCF asks respondents if, in a financial emergency, they could get $\$ 3,000$ from friends or family living outside of their home. Respondents answering in the affirmative likely do so having received substantial financial assistance in the past. Respondents are also asked if they expect to receive future inheritances from other relatives. An expected future inheritance could depress the incentive to save, but it could also be another indicator of a family having already benefitted from inter-vivos assistance that has contributed to the family's accumulated wealth. Each of these indicators for family financial assistance is positively related to a family's ability to amass wealth and explains a substantial portion of the racial wealth gapaccounting for slightly more than one-fifth of the explained component of the white/black and the white/Hispanic wealth gaps. 
Receiving income from a family member in the previous year is negatively, though not significantly, related to wealth, and giving income to a family member not living in the same residence is positively associated with wealth. Neither of these final two measures, however, has a measurable impact on accounting for the racial wealth gap.

\section{Self-Reported Health}

The health status of the respondent and his/her spouse is positively and significantly related to net worth. Healthier family heads are more productive, can work longer, and may also incur fewer medical-related expenses. At the same time, affluent families are able to afford medical care and other services that help them maintain their good health. An indicator for a family head whose self-reported health is "excellent" is correlated with having wealth that is 60 percent greater relative to those respondents who only report having "fair" health (Appendix Table 1). Yet controlling for health status only has a modest impact on the observed racial wealth differences: health status accounts for just 4 percent of the explained white/black wealth gap and for only 2 percent of the wealth gap between white and Hispanic families.

\subsection{Nonparametric (DFL) Results}

Following Barsky et al. (2002), we use the DFL estimator to reweight white families so they then have the same distribution of the traits that are observed for nonwhite families. Despite using a different approach, the DFL reweighting estimator yields results that are similar to those obtained using the O-B decomposition. At the mean of the reweighted distribution, observable variables account for 64 percent of the white/black wealth gap when excluding income and homeownership, and 89 percent once income is included (see Table 5, Panel A). At the median, these observables account for 8 percentage points less of the white/black wealth gap. These same sets of observable variables account for 106 percent and 121 percent, respectively (Panel B), of the mean white/Hispanic wealth gap. For the white/Hispanic wealth gap, at the median of the distribution observable variables account for 79 percent of the wealth difference in wealth before income and homeownership are included in the decomposition, and 90 percent of the wealth gap once income is added.

Across the wealth distribution, there is considerable variation in the extent to which observable variables can account for the wealth gap. At the top of the wealth distribution, there is 
a substantial unexplained portion for the wealth gaps that exist between white families and their black and Hispanic counterparts. At the 90th percentile of the wealth distribution, the unexplained portion is 39 percent for the white/black gap and 20 percent for the white/Hispanic gap. At the bottom of the wealth distribution, observables can account for a considerably larger portion of the wealth gap. At the 10th percentile of the wealth distribution, observable variables account for all of the differences between white and nonwhite families. In the bottom quarter of the distribution, reweighted white families have lower levels of net worth than Hispanic families, with observable factors more than accounting for the wealth gap.

The DFL reweighting estimator can also be used to identify the relative contribution that the individual controls make to the total explained component of the racial wealth gap. Here we focus on the specification that includes income (along with demographic, human capital, real estate, and health variables), but not homeownership. As shown in Table 6, the relative contributions of the different controls is similar to what we found earlier when using the O-B decomposition. At the mean, human capital variables are the most important explanatory factor, accounting for approximately 40 percent of the explained white/nonwhite wealth gaps, followed by demographic variables and family financial assistance, which account for one-quarter and onefifth of the explained gaps, respectively. At the top of the wealth distribution, human capital variables are relatively more important, contributing two-thirds of the explained portion of the white/Hispanic wealth gap at the 95th percentile, but only one-quarter of the explained portion at the 10th percentile. Conditions in local real estate markets play a larger role in the white/nonwhite wealth gaps at the bottom of the distribution, while health makes a more important contribution at the top.

\subsection{Comparisons to Previous Findings on the Racial Wealth Gap in the United States}

Whether using simple OLS regressions, the O-B decomposition, or the DFL reweighting estimator, we find that observable factors (including usual income and homeownership) fully account for the white/Hispanic wealth gap at the mean of the distribution, and explain between 70 and 89 percent of the white/black wealth gap. The portion of the white/black wealth gap we can account for in this paper is toward the high end of most prior research results. Scholz and Levine (2003, p. 10) conducted a thorough review of previous studies and found that the portion of the white/black wealth gap most researchers accounted for was "between 12 and 84 percent, with most 
falling between 20 and 35 percent." ${ }^{26}$ Most of the existing literature uses the Panel Study of Income Dynamics, although a couple of studies use the National Longitudinal Survey of Youth and a couple others use the 1989 SCF.

Some of the differences between our findings and previous research results is because this paper is based on much more recent data than all of the prior studies reviewed by Scholz and Levine (2003). Moreover, in this paper we attempt to overcome many of the limitations of the earlier literature identified by Scholz and Levine. Our approach includes using the high-quality wealth data in the SCF since, compared to most previous data, this survey is representative of the entire US wealth distribution. We analyze the racial wealth gap across the entire distribution, not simply at the mean, and incorporate a wide range of observable factors that may potentially account for the wealth gap.

Our findings are also very similar to previous research on the white/Hispanic wealth gap. Using data from nine waves of the Survey of Income and Program Participation data through 2001, Cobb-Clark and Hildebrand (2006) find that their observable factors explain essentially all of the wealth gap between non Hispanic white households and those of Mexican origin (separately for native and foreign-born) households. They also show that education is the most important contributing factor to this portion of the wealth gap, and that the effect from education, which contributes to human capital, is larger at the top of the wealth distribution.

\section{Conclusions}

There are large and persistent unconditional differences in the wealth of white and nonwhite families living in the United States. These differences often mirror substantial differences in observable traits known to be related to the process of wealth accumulation. This paper discusses the findings of some simple OLS regressions and decompositions that try to account for these persistent differences. The findings suggest that nearly all of the white/Hispanic wealth gap at the mean and the median of the US wealth distribution can be accounted for by differences in observable traits, with differences in basic demographic characteristics and

\footnotetext{
${ }^{26}$ Papers using white-based weights or coefficients tend to explain a larger share of the racial wealth gap, with these estimates falling between the extremes of 5 percent and 120 percent, though most of the findings fall between 60 and 90 percent. (Scholz and Levine 2003, p. 10). Because there is an absence of common support at the top of distribution, with essentially only white families present at the very top of the income and wealth distributions, the estimates using white-based weights cannot reliably serve as a counterfactual for the black wealth distribution.
} 
educational attainment accounting for most of the wealth gap. Most of the white/black wealth gap can also be accounted for by differences in observable characteristics, particularly human capital, demographic traits, and whether a family receives financial support, including inheritances, from other relatives. Using the full set of observable characteristics discussed in this paper, including usual income but not homeownership, we can account for 89 percent of the observed mean wealth differences between white and black families when using the preferred nonparametric decomposition method from DiNardo, Fortin, and Lemieux (1996). While all of the wealth gap between white and black families is due to differences in assets, the gap between Hispanic and black families is more balanced between assets and debt. Observable factors account for much less of the racial wealth gap observed at the top of the distribution. 


\section{References}

Altonji, Joseph G., and Ulrich Doraszelski. 2005. "The Role of Permanent Income and Demograhics in Black/White Differences in Wealth." Journal of Human Resources 40(1): 1-30.

Barsky, Robert, John Bound, Kerwin Kofi Charles, and Joseph P. Lupton. 2002. "Accounting for the Black-White Wealth Gap: A Nonparametric Approach." Journal of the American Statistical Association 97(459): 663-673.

Bayer, Patrick, Fernando Ferreira, and Stephen Ross. 2018. "What Drives Racial and Ethnic Differences in High Cost Mortgages? The Role of High Risk Lenders." Review of Financial Studies 32(1): 175-202.

Blinder, Alan S. 1973. "Wage Discrimination: Reduced Form and Structural Estimates." Journal of Human Resources 8(4): 436-455.

Bricker, Jesse, Lisa J. Dettling, Alice Henriques, Joanne W. Hsu, Lindsay Jacobs, Kevin B. Moore, Sarah Pack, John Sabelhaus, Jeffrey Thompson, and Richard A. Windle. 2017. "Changes in U.S. Family Finances from 2013 to 2016: Evidence from the Survey of Consumer Finances." Federal Reserve Bulletin 103(3):1-42.

Bricker, Jesse, Alice M. Henriques, Jake A. Krimmel, and John E. Sabelhaus. 2016. "Measuring Income and Wealth at the Top Using Administrative and Survey Data." Brookings Papers on Economic Activity (Spring): 261-331.

Browning, Martin, and Annamaria Lusardi. 1996. "Household Saving: Micro Theories and Micro Facts," Journal of Economic Literature 34(4): 1797-1855.

Charles, Kerwin Kofi, and Erik Hurst, 2002. "The Transition to Home Ownership and the BlackWhite Wealth Gap.” Review of Economics and Statistics 84(2): 281-297.

Chen, Yong, and Stuart S. Rosenthal. 2008. "Local Amenities and Life-Cycle Migration: Do People Move for Jobs or Fun?” Journal of Urban Economics 64(3): 519-537.

Cobb-Clark, Deborah A., and Vincent A. Hildebrand. 2006. "The Wealth of Mexican Americans." Journal of Human Resources 41(4): 841-867.

Dettling, Lisa J., Joanne W. Hsu, Lindsay Jacobs, Kevin B. Moore, and Jeffrey P. Thompson. 2017. "Recent Trends in Wealth-Holding by Race and Ethnicity: Evidence from the Survey of Consumer Finances.” FEDS Notes 2017-09-27. Washington: Board of Governors of the Federal Reserve System.

Diamond, Peter and Jerry Hausman, 1984. "Individual Retirement and Savings Behavior," Journal of Public Economics, 23(1/2), 81-114.

DiNardo, John, Nicole M. Fortin, and Thomas Lemieux. 1996. "Labor Market Institutions and the Distribution of Wages, 1973-1993: A Semiparametric Approach.” Econometrica 64(5): 10011044.

DiNardo, John. 2002. "Propensity Score Reweighting and Changes in Wage Distributions." Working Paper. http://www-personal.umich.edu/ jdinardo/bztalk5.pdf. 
Fortin, Nicole, Thomas Lemieux, and Sergio Firpo. 2011. "Decomposition Methods in Economics." In Handbook of Labor Economics, 4thVolume, Part A, edited by Orley C. Ashenfelter and David Card, 1-102. Amsterdam: Elsevier North Holland.

Fryer, Roland G., Jr., Jorg Spenkuch, and Devah Pager, 2013. "Racial Disparities in Job Finding and Offered Wages." Journal of Law and Economics 56 (3): 633-689.

Jann, Ben. 2008. "The Oaxaca-Blinder Decomposition for Linear Regression Models." The Stata Journal 8(4):453-479.

Kennickell, Arthur B. 1998. "List Sample Design for the 1998 Survey of Consumer Finances." Working Paper. Washington: Board of Governors of the Federal Reserve System. https://www.federalreserve.gov/econresdata/scf/files/listsample.pdf.

Kennickell, Arthur B. 1999. "Revisions to the SCF Weighting Methodology: Accounting for Race/Ethnicity and Homeownership." Working Paper. Washington: Board of Governors of the Federal Reserve System.

https://www.federalreserve.gov/econresdata/scf/files/weightrevision.pdf.

Menchik, Paul L., and Nancy Ammon Jianakoplos. 1997. "Black-White Wealth Inequality: Is Inheritance the Reason?" Economic Inquiry 35(2): 428-442.

Oaxaca, Ronald. 1973. "Male-Female Wage Differentials in Urban Labor Markets.” International Economic Review 14(3): 693-709.

Pence, Karen M. 2006. "The Role of Wealth Transformations: An Application to Estimating the Effect of Tax Incentives on Saving." B.E. Journals in Economic Analysis and Policy: Contributions to Economic Analysis and Policy 5(1): 1-24.

Rosenbaum, Paul R., and Donald B. Rubin. 1983. "The Central Role of the Propensity Score in Observational Studies for Causal Effects." Biometrika 70(1): 41-55.

Scholz, John Karl, and Kara Levine. 2003. "U.S. Black-White Wealth Inequality: A Survey.” Working Paper. Madison: University of Wisconsin.

https://ssc.wisc.edu/ scholz/Research/Wealth_survey_v5.pdf.

Scholz, John Karl, and Anath Seshadri. 2007. "Children and Household Wealth," Michigan Retirement Research Center Research Paper No. WP 2007-158.

https://dx.doi.org/10.2139/ssrn.1083829.

Shapiro, Thomas, Tatjana Meschede, and Sam Osoro. 2013. "The Roots of the Widening Racial Wealth Gap: Explaining the Black-White Economic Divide." Institute on Assets and Social Policy Research Brief (February), Heller School for Social Policy and Management. Waltham, MA: Brandeis University. https://heller.brandeis.edu/iasp/pdfs/racial-wealth-equity/racialwealth-gap/roots-widening-racial-wealth-gap.pdf.

Sharp, Gregory, and Matthew Hall. 2014. "Emerging Forms of Racial Inequality in Homeownership Exit, 1968-2009.” Social Problems 61(3): 427-447.

Thompson, Jeffrey P., and Gustavo A. Suarez. 2015. "Exploring the Racial Wealth Gap Using the Survey of Consumer Finances, Finance and Economics Discussion Series 2015-076. Washington: Board of Governors of the Federal Reserve System. 
Wilson, Oliver H., and William J. Smith. 1984. "Access to Tax Records for Statistical Purposes." Review of Public Use Data 12(4): 295-305.

Wolff, Edward N. 2016. "Household Wealth Trends in the United States, 1962-2013: What Happened over the Great Recession?" Russell Sage Foundation Journal of the Social Sciences 2(6): 24-43. 
Figure 1. Trends in White/Black Wealth Ratios Accounting for Sampling Error and Sensitivity to Distribution Tails

1A. Range of the White/Black Mean Wealth Ratio (Boundaries of 95 Percent Confidence Interval)

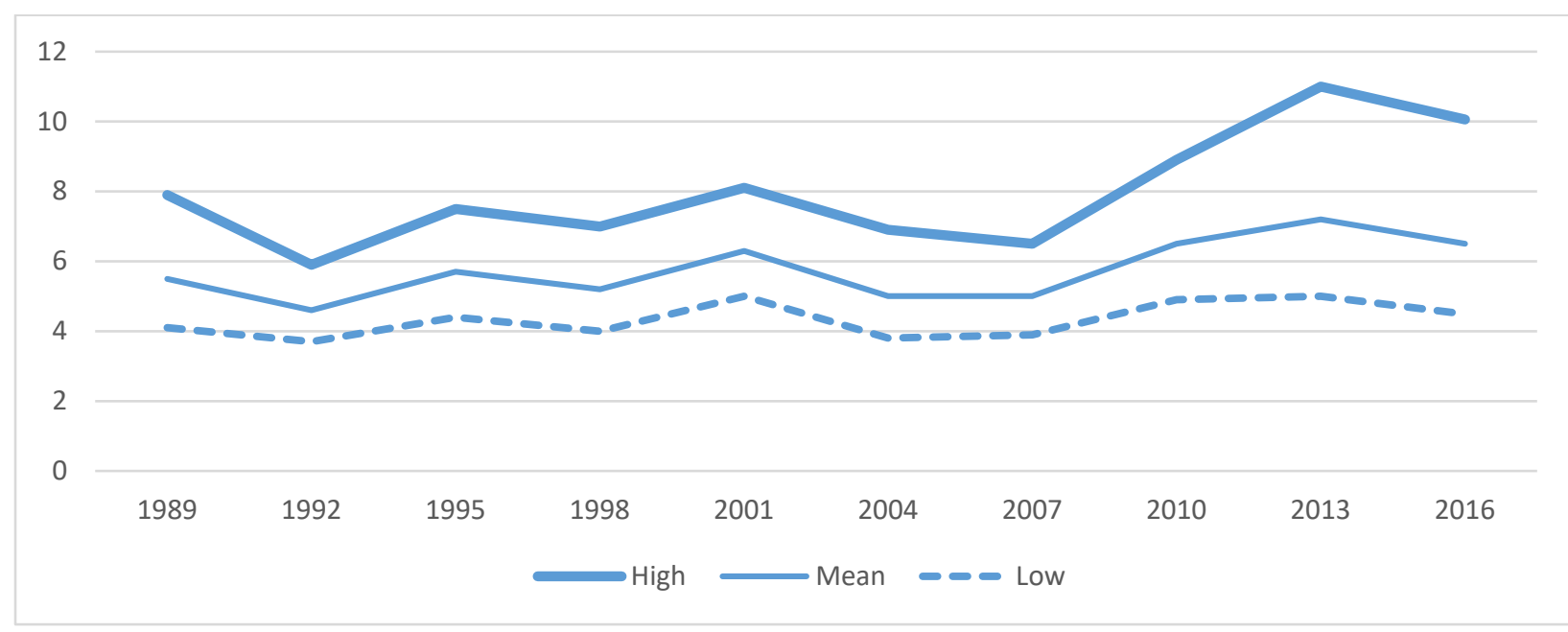

1B. Ratios of White/Black Wealth Means by Sensitivity to Tails of Distribution

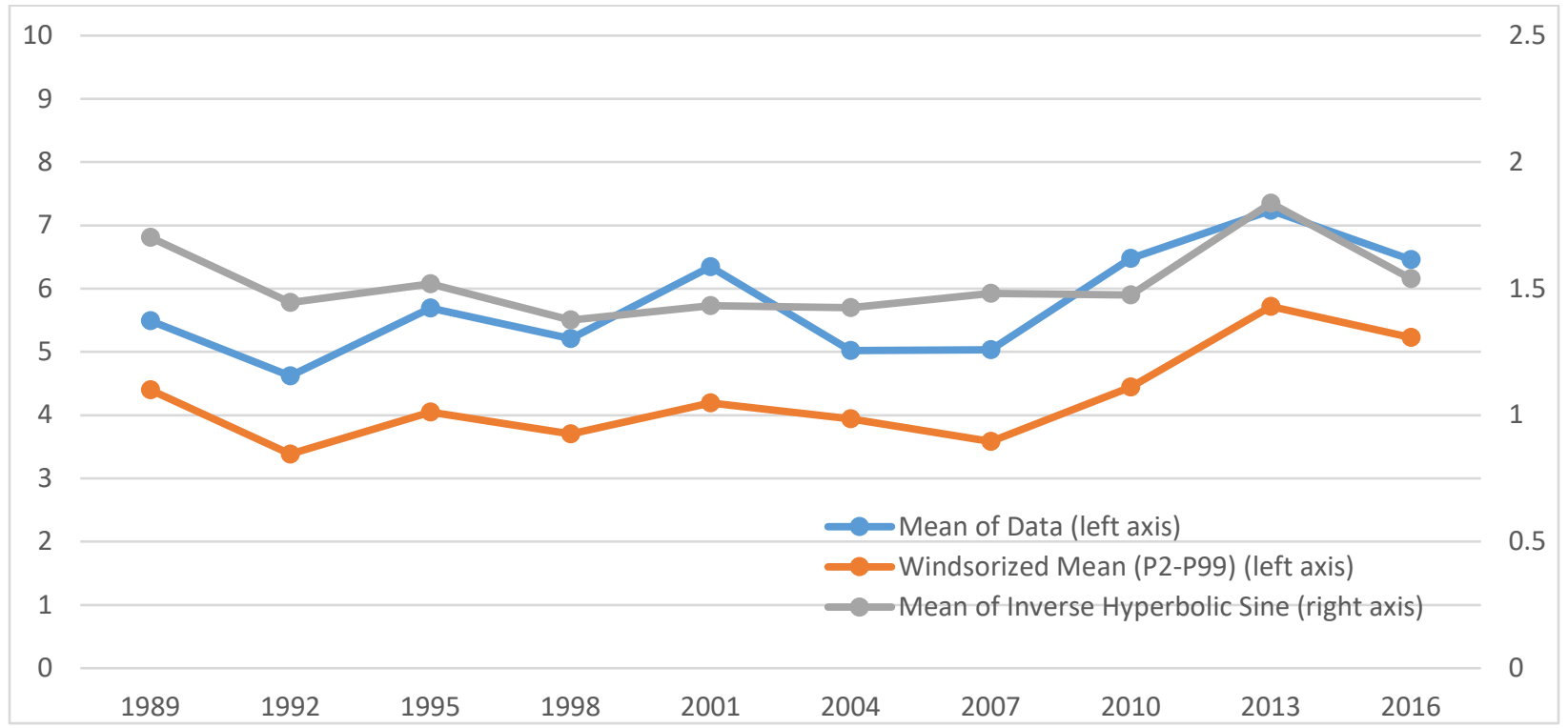

Source: Authors' Analysis of Survey of Consumer Finances (1989-2016). Figures show white/black ratios of different estimates of mean family wealth. 1A shows the ratio of mean family net worth (thin blue line), as well as the ratio of the upper-bound of the 95-percent confidence interval of mean white family net worth to the lower-bound of the 95-percent confidence interval of mean black family net worth (thick blue line), and the ratio of the lower-bound of 95-percent confidence interval of mean white family wealth to the upper-bound of the 95-percent confidence interval of mean black family net worth (dashed line). 1B shows ratios of white/black net worth using unadjusted net worth (blue line), as well as means of windsorized net worth, which excludes the top and bottom one percent of the distribution (orange line), and the means of the inverse hyperbolic sine transformation of net worth (gray line). 
Figure 2. Respondent Age and Wealth Profiles in the 2016 Survey of Consumer Finances

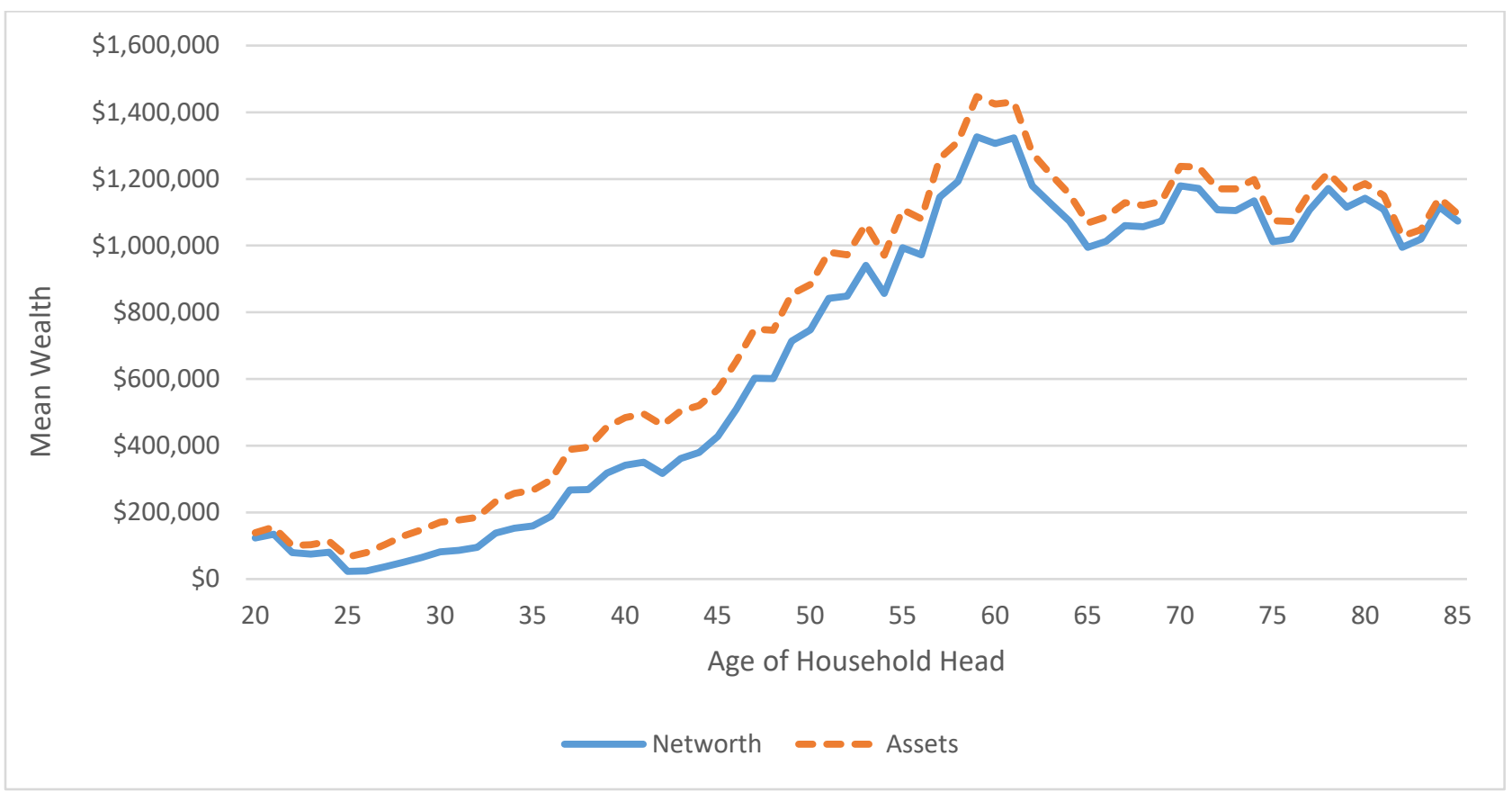

Source: Authors' analysis of 2016 Survey of Consumer Finances. Figure shows 3-year (age of family head) moving average of mean assets (orange dashed line) and net worth (blue line).

Figure 3. Median Net Worth by Age for White, Black, and Hispanic Families in the Survey of Consumer Finances

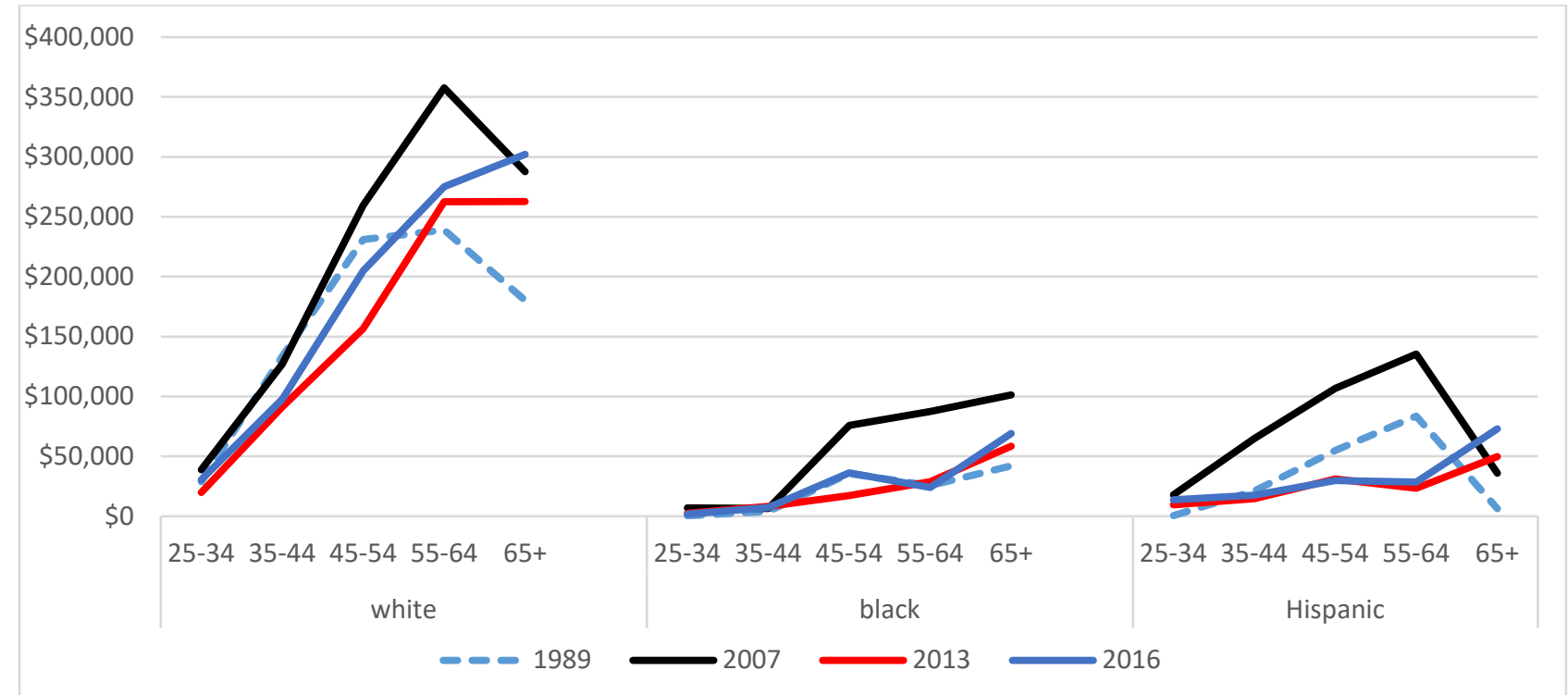

Source: Authors' analysis of Survey of Consumer Finances (1989, 2007, 2013, and 2016). Figure shows median net worth by age group of family head, separately for white, black, and Hispanic families. 
Table 1: Summary Statistics by Race (2001-2016)

\begin{tabular}{|c|c|c|c|c|}
\hline & $\begin{array}{c}(1) \\
\text { Total }\end{array}$ & $\begin{array}{c}(2) \\
\text { White }\end{array}$ & $\begin{array}{c}(3) \\
\text { Black }\end{array}$ & $\begin{array}{c}(4) \\
\text { Hispanic }\end{array}$ \\
\hline Share of Households: & 100 & 72 & 14 & 10 \\
\hline Net Worth (Mean) & 593,544 & 744,944 & 124,300 & 153,309 \\
\hline Assets (Mean) & 691,147 & 851,936 & 181,325 & 221,343 \\
\hline Debt (Mean) & 97,603 & 106,993 & 57,025 & 68,034 \\
\hline Respondent Age (Mean) & 50.4 & 52.2 & 47.7 & 43.0 \\
\hline Number of Children Living in Household (Mean) & 0.81 & 0.71 & 0.93 & 1.33 \\
\hline Number of Children Living Elsewhere (Mean) & 1.5 & 1.5 & 1.6 & 1.4 \\
\hline Share with "Nonprimary" Family Member Living t in Household & 12 & 10 & 14 & 21 \\
\hline \multicolumn{5}{|l|}{ Family Structure (Percentage Shares by Family Type) } \\
\hline Unmarried (Nonpartnered) with Children & 12 & 09 & 27 & 16 \\
\hline Unmarried (Nonpartnered), No Children, Head Less than 55 Years & 15 & 13 & 18 & 14 \\
\hline Unmarried (Nonpartnered), No Children, Head 55 Years or older & 15 & 17 & 17 & 06 \\
\hline Married (Partnered) with Children & 31 & 30 & 22 & 46 \\
\hline Married (Partnered), No Children & 27 & 31 & 16 & 17 \\
\hline Divorced & 16 & 17 & 19 & 14 \\
\hline \multicolumn{5}{|l|}{ Urban Locale (Percentage Shares by Location Type) } \\
\hline Resides in Metropolitan Statistical Area & 85 & 83 & 89 & 94 \\
\hline Resides outside Metropolitan Statistical Area & 15 & 17 & 11 & 06 \\
\hline \multicolumn{5}{|l|}{ Education of Respondent (Percentage Shares by Attainment) } \\
\hline Less than High School Diploma & 15 & 11 & 20 & 40 \\
\hline High School Diploma Only & 29 & 29 & 31 & 27 \\
\hline Some College, No Degree & 18 & 18 & 22 & 14 \\
\hline Community College/Two-Year Associate's Degree & 07 & 07 & 07 & 06 \\
\hline BA/Four-Year College & 19 & 21 & 12 & 09 \\
\hline Advanced Degree & 12 & 13 & 07 & 04 \\
\hline \multicolumn{5}{|l|}{ Education of Spouse (Percentage Shares by Attainment) } \\
\hline Less than High School Diploma & 12 & 08 & 11 & 37 \\
\hline High School Diploma Only & 28 & 29 & 30 & 27 \\
\hline Some College, No Degree & 17 & 17 & 19 & 13 \\
\hline Community College/Two-Year Associate's Degree & 10 & 10 & 10 & 07 \\
\hline Four-Year College Degree & 21 & 22 & 17 & 08 \\
\hline Advanced Degree & 12 & 13 & 08 & 04 \\
\hline
\end{tabular}


Table 1: Summary Statistics (Continued)

\begin{tabular}{|c|c|c|c|c|}
\hline & $\begin{array}{l}(1) \\
\text { Total }\end{array}$ & $\begin{array}{c}(2) \\
\text { White }\end{array}$ & $\begin{array}{c}(3) \\
\text { Black }\end{array}$ & $\begin{array}{c}(4) \\
\text { Hispanic }\end{array}$ \\
\hline \multicolumn{5}{|l|}{ Occupation 1 (Percentage Shares by Category) } \\
\hline Employed by Someone Else & 58 & 56 & 60 & 71 \\
\hline Self-employed/Partnership & 11 & 12 & 06 & 09 \\
\hline Retired, Disabled, Student, Homemaker & 25 & 28 & 25 & 14 \\
\hline Not in Labor Force, Other Not Working & 05 & 04 & 09 & 06 \\
\hline \multicolumn{5}{|l|}{ Occupation 2 (Percentage Shares by Category) } \\
\hline Managerial, Professional & 28 & 30 & 21 & 16 \\
\hline Technical, Sales, Services & 22 & 20 & 27 & 28 \\
\hline $\begin{array}{l}\text { Other (Incl. Production/Craft/Repair workers, Operators, Laborers, } \\
\text { Farmers, Foresters, Fishers) }\end{array}$ & 20 & 18 & 18 & 35 \\
\hline Not Working & 31 & 32 & 34 & 20 \\
\hline \multicolumn{5}{|l|}{ Industry (Percentage Shares by Category) } \\
\hline Mining, Construction, Manufacturing & 17 & 17 & 11 & 25 \\
\hline Transportation, Communication, Utilities & 14 & 14 & 12 & 12 \\
\hline Wholesale Trade, Finance, Insurance, Real Estate & 39 & 38 & 43 & 44 \\
\hline Agriculture, Retail, Services, Public Administration & 31 & 32 & 34 & 20 \\
\hline Total Full-Time Work Years of Respondent (Mean) & 24.4 & 26.1 & 21.5 & 18.7 \\
\hline Total Full-Time Work Years of Spouse (Mean) & 9.2 & 10.2 & 6.0 & 6.5 \\
\hline Percentage of Families with Inheritance Received & 20 & 25 & 10 & 05 \\
\hline Inherit Residence? & 04 & 04 & 05 & 02 \\
\hline Inherit Business? & 01 & 01 & 00 & 00 \\
\hline Inherit Other Real Estate? & 03 & 03 & 03 & 01 \\
\hline Total Inheritances Received (Mean) (\$) & 50,029 & 63,787 & 12,911 & 6,485 \\
\hline Conditional Total Inheritances Received (Mean) (\$) & 172,099 & 182,046 & 93,547 & 64,995 \\
\hline Years Since Last Inheritance (conditional) (Mean) & 8.3 & 8.5 & 9.5 & 4.6 \\
\hline Percent of Households Expecting Inheritance in the Future & 13 & 15 & 05 & 06 \\
\hline Percent that Can get $\$ 3,000$ from Family/Friends in Emergency & 65 & 72 & 43 & 48 \\
\hline Income Received from Relatives Last Year (\$) (Mean) & 124 & 113 & 101 & 86 \\
\hline Income Given to Relatives Last Year (\$) (Mean) & 1,283 & 1,442 & 854 & 580 \\
\hline Quality-Adjusted Rent by Metropolitan Statistical Area (Mean) & 8,777 & 8,518 & 8,618 & 9,908 \\
\hline One-Year Growth in House Price Index (Mean) & 5.8 & 5.3 & 6.0 & 7.9 \\
\hline Five-Year Growth in House Price Index (Mean) & 22.3 & 20.9 & 22.8 & 28.0 \\
\hline Ten-Year Growth in House Price Index (Mean) & 38.4 & 37.3 & 38.4 & 41.8 \\
\hline Years of Tenure in Current Residence (Mean) & 11.3 & 12.4 & 9.7 & 7.3 \\
\hline
\end{tabular}


Table 1: Summary Statistics (Continued)

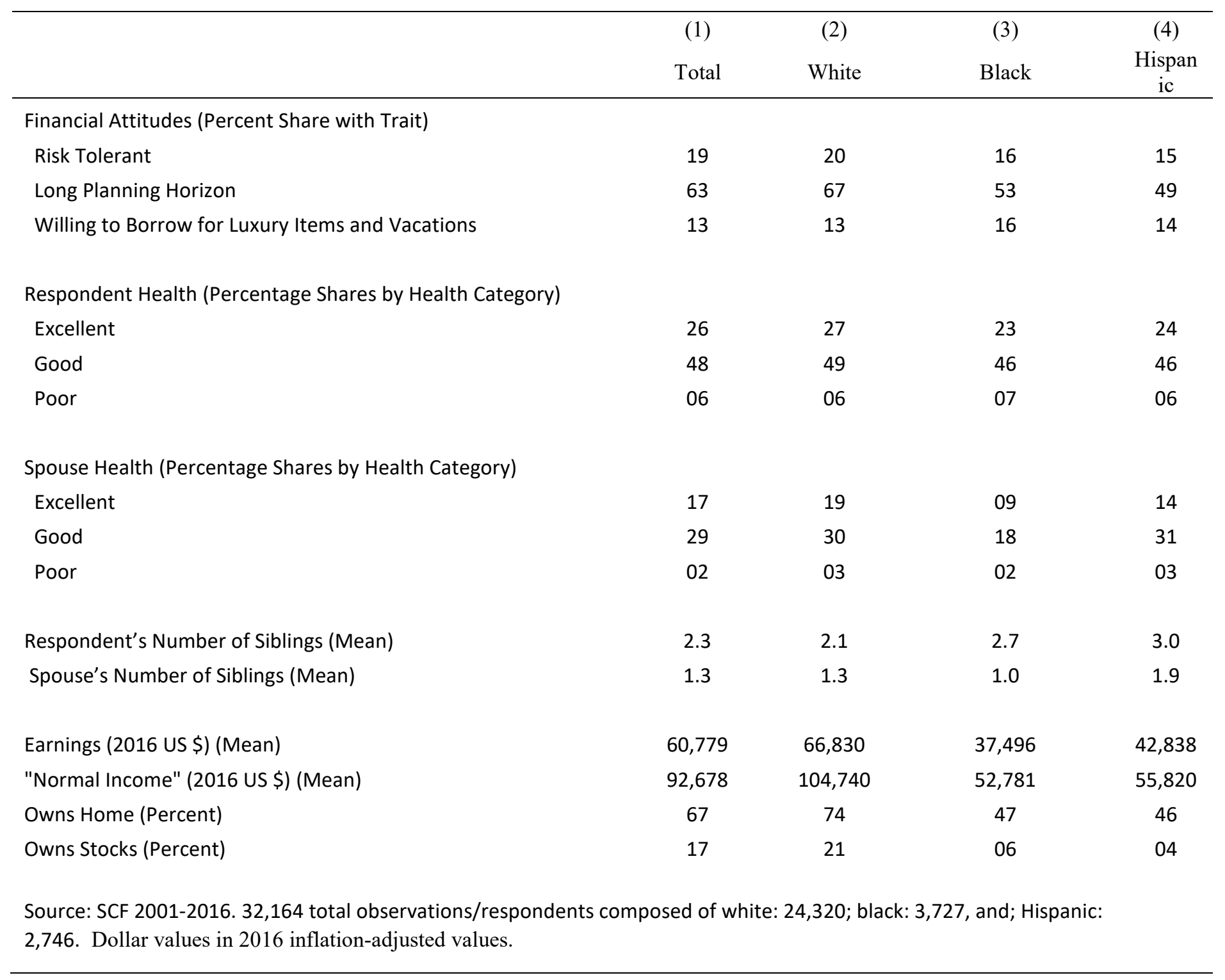


Table 2: Assets, Debt, and Net Worth by Race

\begin{tabular}{|c|c|c|c|c|c|c|c|c|c|c|c|c|c|c|c|}
\hline Panel A & \multirow{3}{*}{$\begin{array}{c}(1) \\
\text { White }\end{array}$} & \multirow[b]{2}{*}{ (2) } & \multirow{2}{*}{$\begin{array}{l}\text { Assets } \\
\text { (3) }\end{array}$} & \multicolumn{2}{|c|}{$\begin{array}{c}\text { White Family } \\
\text { Assets Relative } \\
\text { to: }\end{array}$} & \multirow[b]{2}{*}{ (6) } & & Debt & $\begin{array}{r}\text { Whit } \\
\text { Debt } \mathrm{R}\end{array}$ & $\begin{array}{l}\text { amily } \\
\text { tive to: }\end{array}$ & & & Tet Worth & $\begin{array}{r}\text { Whit } \\
\text { Net } \\
\text { Relc }\end{array}$ & $\begin{array}{l}\text { Family } \\
\text { Worth } \\
\text { tive to: }\end{array}$ \\
\hline & & & & (4) & (5) & & (7) & (8) & (9) & $(10)$ & (11) & (12) & (13) & (14) & $(15)$ \\
\hline & & Black & Hispanic & Black & Hispanic & White & Black & Hispanic & Black & Hispanic & White & Black & Hispanic & Black & Hispanic \\
\hline 1989 & 477,818 & 98,097 & 122,979 & 4.9 & 3.9 & 53,424 & 20,782 & 38,464 & 2.6 & 1.4 & 424,393 & 77,314 & 84,516 & 5.5 & 5.0 \\
\hline 1992 & 431,818 & 104,976 & 126,136 & 4.1 & 3.4 & 58,808 & 24,235 & 35,433 & 2.4 & 1.7 & 373,011 & 80,741 & 90,703 & 4.6 & 4.1 \\
\hline 1995 & 455,063 & 97,824 & 136,749 & 4.7 & 3.3 & 61,948 & 28,733 & 40,487 & 2.2 & 1.5 & 393,115 & 69,091 & 96,262 & 5.7 & 4.1 \\
\hline 1998 & 570,366 & 131,853 & 168,338 & 4.3 & 3.4 & 76,140 & 37,032 & 40,076 & 2.1 & 1.9 & 494,226 & 94,821 & 128,262 & 5.2 & 3.9 \\
\hline 2001 & 738,803 & 146,749 & 167,867 & 5.0 & 4.4 & 81,702 & 43,194 & 43,806 & 1.9 & 1.9 & 657,101 & 103,555 & 124,060 & 6.3 & 5.3 \\
\hline 2004 & 817,130 & 195,281 & 228,337 & 4.2 & 3.6 & 110,463 & 54,558 & 67,379 & 2.0 & 1.6 & 706,666 & 140,723 & 160,958 & 5.0 & 4.4 \\
\hline 2007 & 899,953 & 234,210 & 315,681 & 3.8 & 2.9 & 116,496 & 78,553 & 100,900 & 1.5 & 1.2 & 783,457 & 155,656 & 214,781 & 5.0 & 3.6 \\
\hline 2010 & 822,770 & 165,493 & 190,975 & 5.0 & 4.3 & 120,984 & 57,101 & 70,826 & 2.1 & 1.7 & 701,786 & 108,393 & 120,149 & 6.5 & 5.8 \\
\hline 2013 & 814,266 & 151,145 & 172,957 & 5.4 & 4.7 & 105,174 & 53,153 & 57,354 & 2.0 & 1.8 & 709,091 & 97,992 & 115,603 & 7.2 & 6.1 \\
\hline 2016 & $1,010,592$ & 196,144 & 246,977 & 5.2 & 4.1 & 106,303 & 56,182 & 65,010 & 1.9 & 1.6 & 904,289 & 139,962 & 181,968 & 6.5 & 5.0 \\
\hline
\end{tabular}


Table 2: Assets, Debt, and Net Worth by Race (continued)

\begin{tabular}{|c|c|c|c|c|c|c|c|c|c|c|c|c|c|c|c|}
\hline \multicolumn{2}{|c|}{ Panel B: Medians } & \multirow[b]{3}{*}{ (2) } & \multirow{3}{*}{$\begin{array}{c}\text { Assets } \\
\text { (3) }\end{array}$} & \multirow{2}{*}{\multicolumn{2}{|c|}{$\begin{array}{c}\text { White Family } \\
\text { Assets Relative to: }\end{array}$}} & \multicolumn{5}{|c|}{ Debt } & \multicolumn{5}{|c|}{ Net Worth } \\
\hline & \multirow[b]{2}{*}{ (1) } & & & & & \multirow[b]{2}{*}{ (6) } & \multirow[b]{2}{*}{ (7) } & \multirow[b]{2}{*}{$(8)$} & \multicolumn{2}{|c|}{$\begin{array}{l}\text { White Family } \\
\text { Debt Relative to: }\end{array}$} & \multirow[b]{2}{*}{ (11) } & \multirow[b]{2}{*}{ (12) } & \multirow[b]{2}{*}{ (13) } & \multicolumn{2}{|c|}{$\begin{array}{c}\text { White Family } \\
\text { Net Worth } \\
\text { Relative to: }\end{array}$} \\
\hline & & & & (4) & $(5)$ & & & & (9) & $(10)$ & & & & (14) & (15) \\
\hline & White & Black & Hispanic & Black & Hispanic & White & Black & Hispanic & Black & Hispanic & White & Black & Hispanic & Black & Hispanic \\
\hline 1989 & 180,942 & 13,451 & 15,113 & 13.5 & 12.0 & 13,798 & 1,552 & 5,411 & 8.9 & 2.6 & 132,749 & 7,445 & 9,749 & 17.8 & 13.6 \\
\hline 1995 & 182,518 & 29,754 & 45,492 & 6.1 & 4.0 & 18,009 & 2,647 & 11,902 & 6.8 & 1.5 & 120,015 & 17,096 & 19,046 & 7.0 & 6.3 \\
\hline 1998 & 209,618 & 37,329 & 38,812 & 5.6 & 5.4 & 23,607 & 4,198 & 5,754 & 5.6 & 4.1 & 140,225 & 22,833 & 14,495 & 6.1 & 9.7 \\
\hline 2001 & 243,545 & 59,139 & 24,794 & 4.1 & 9.8 & 26,149 & 8,129 & 5,419 & 3.2 & 4.8 & 164,528 & 25,769 & 15,386 & 6.4 & 10.7 \\
\hline 2004 & 277,407 & 53,574 & 40,379 & 5.2 & 6.9 & 38,806 & 11,206 & 8,830 & 3.5 & 4.4 & 173,789 & 25,975 & 19,973 & 6.7 & 8.7 \\
\hline 2007 & 297,074 & 56,916 & 62,185 & 5.2 & 4.8 & 38,215 & 13,394 & 16,212 & 2.9 & 2.4 & 189,303 & 19,778 & 24,376 & 9.6 & 7.8 \\
\hline 2010 & 253,156 & 44,213 & 44,504 & 5.7 & 5.7 & 40,897 & 9,186 & 11,075 & 4.5 & 3.7 & 136,508 & 17,138 & 16,560 & 8.0 & 8.2 \\
\hline 2013 & 236,484 & 32,933 & 34,465 & 7.2 & 6.9 & 31,813 & 10,311 & 8,249 & 3.1 & 3.9 & 138,290 & 11,412 & 14,152 & 12.1 & 9.8 \\
\hline 2016 & 258,931 & 44,800 & 47,683 & 5.8 & 5.4 & 33,600 & 15,634 & 10,000 & 2.1 & 3.4 & 162,550 & 16,555 & 21,482 & 9.8 & 7.6 \\
\hline
\end{tabular}

Source: Authors' analysis of Survey of Consumer Finances (1989-2016). The table shows means (Panel A) and medians (Panel B) of assets, debts, and net worth by year and racial group. Ratios of white to non-white assets are shown in columns 4 and 5; for debt in columns 9 and10, and; for net worth in columns 14 and 15 . 
Table 3: OLS Key Coefficients, by Dependent Variables and Inclusion of Income and Housing

This table reports estimated coefficients for key predictors, with the inverse hyperbolic sine of net worth, assets and debt as dependent variables using data from the Survey of Consumer Finances from 2001 to 2016. Specification (1) includes only year fixed effects. Specification (2) includes the full range of demographic, education, real estate, labor force, inheritance, and other explanatory variables from Table 2, with the exception of usual income and homeownership. (The full results from this specification using net worth are shown in Appendix Table 1). These final control variables are added, separately, in columns (3) and (4), and then simultaneously in (5). Panel A summarizes results for net worth as dependent variable, and Panels B and C report results with assets and debt, respectively, as dependent variables. Coefficients are reported with standard errors in parentheses, and ${ }^{*},{ }^{*}$, and $* * *$ indicate significance at the 10 percent, 5 percent, and 1 percent levels, respectively.

Panel A. Net Worth Regressions

\begin{tabular}{|c|c|c|c|c|c|}
\hline & $(1)$ & $(2)$ & (3) & $(4)$ & $(5)$ \\
\hline \multirow[t]{3}{*}{ White } & 3.7293 & 1.1696 & 0.9266 & 0.6255 & 0.4836 \\
\hline & $(0.0987)$ & $(0.1512)$ & (0.1509) & $(0.1455)$ & $(0.1457)$ \\
\hline & $* * *$ & $* * *$ & $* * *$ & $* * *$ & $* * *$ \\
\hline \multirow[t]{3}{*}{ Hispanic } & 1.1248 & 1.1437 & 1.1431 & 0.8810 & 0.9025 \\
\hline & (0.1494) & $(0.2046)$ & $(0.2071)$ & (0.1961) & (0.1984) \\
\hline & $* * *$ & $* * *$ & $* * *$ & $* * *$ & $* * *$ \\
\hline \multirow[t]{3}{*}{ Normal Income (IHS) } & & & 1.4811 & & 1.142 \\
\hline & & & $(0.0830)$ & & $(0.0726)$ \\
\hline & & & $* * *$ & & $* * *$ \\
\hline \multirow[t]{3}{*}{ Homeownership } & & & & 4.1361 & 3.7906 \\
\hline & & & & $(0.1254)$ & $(0.1267)$ \\
\hline & & & & $* * *$ & $* * *$ \\
\hline \multirow[t]{3}{*}{ Constant } & 7.5036 & 0.8100 & -14.2196 & 2.0019 & -9.6853 \\
\hline & $(0.1030)$ & (1.1174) & (1.3999) & (1.0966) & (1.3076) \\
\hline & $* * *$ & & $* * *$ & $*$ & $* * *$ \\
\hline
\end{tabular}

Panel B. Assets Regressions

\begin{tabular}{|c|c|c|c|c|c|}
\hline & $(1)$ & (2) & (3) & (4) & $(5)$ \\
\hline \multirow[t]{3}{*}{ White } & 2.2726 & 0.7656 & 0.6042 & 0.4393 & 0.3420 \\
\hline & (0.0419) & $(0.0488)$ & $(0.0468)$ & $(0.0425)$ & $(0.0411)$ \\
\hline & $* * *$ & $* * *$ & $* * *$ & $* * *$ & $* * *$ \\
\hline \multirow[t]{3}{*}{ Hispanic } & 0.201 & 0.4153 & 0.4150 & 0.2578 & 0.2726 \\
\hline & $(0.0601)$ & $(0.0679)$ & (0.0699) & $(0.0583)$ & $(0.0604)$ \\
\hline & $* * *$ & $* * *$ & $* * *$ & $* * *$ & $* * *$ \\
\hline
\end{tabular}

Panel C. Debt Regressions

\begin{tabular}{|c|c|c|c|c|c|}
\hline & (1) & (2) & (3) & (4) & (5) \\
\hline \multirow[t]{3}{*}{ White } & 0.8271 & 0.4719 & 0.3461 & -0.0814 & -0.1313 \\
\hline & (0.0709) & $(0.0954)$ & $(0.0926)$ & (0.0879) & $(0.0866)$ \\
\hline & $* * *$ & $* * *$ & $* * *$ & & \\
\hline \multirow[t]{3}{*}{ Hispanic } & -0.2296 & -0.3139 & -0.3142 & -0.581 & -0.5734 \\
\hline & $(0.0910)$ & $(0.1308)$ & (0.1285) & (0.1227) & (0.1216) \\
\hline & $* *$ & $* *$ & $* *$ & $* * *$ & $* * *$ \\
\hline
\end{tabular}




\section{Table 4: Decomposition of the Wealth Gap (Oaxaca/Blinder) by Racial Groups and Selected Control}

Variables

This table summarizes the Oaxaca-Blinder (O-B) decomposition for the wealth gap across racial groups using data from the Survey of Consumer Finances from 2001 to 2016. The O-B decomposition assumes a linear relationship between the explanatory and the dependent variables, and with the goal of obtaining counterfactual estimates. Panel A shows summary measures of decomposition, highlighting the share of the total gap that is explained by observable variables. Panel B shows the share of the total explained portion of the wealth gap that can be accounted for by groups of observables. The decomposition of the white/black wealth gap are shown in columns (1), (2), and (3); the results for the white/Hispanic decomposition are shown in Columns (4), (5), and (6). Three separate decomposition specifications are shown for each white/nonwhite comparison. Columns (1) and (4) include the broad range of demographic, human capital, and other control variables, but does not include income or homeownership. The full list of control variables is shown in the OLS specification results in Appendix Table 1. Columns (2) and (5) add a control for usual income. Columns (3) and (6) also add an indicator variable for homeownership.

\begin{tabular}{ccc}
\hline \multicolumn{3}{c}{ White/Black } \\
\hline $\begin{array}{l}\text { All covariates, } \\
\text { excluding } \\
\text { income and } \\
\text { homeownership }\end{array}$ & $\begin{array}{l}\text { Adding } \\
\text { income }\end{array}$ & $\begin{array}{c}\text { Adding } \\
\text { homeownership }\end{array}$ \\
\hline (1) & (2) & (3) \\
\hline
\end{tabular}

\begin{tabular}{lcc}
\hline \multicolumn{3}{c}{ White/Hispanic } \\
\hline $\begin{array}{l}\text { All covariates, } \\
\text { excluding } \\
\text { income and } \\
\text { homeownership }\end{array}$ & $\begin{array}{l}\text { Adding } \\
\text { income }\end{array}$ & $\begin{array}{c}\text { Adding } \\
\text { homeownership }\end{array}$ \\
\hline $\mathbf{( 4 )}$ & $\mathbf{( 5 )}$ & $\mathbf{( 6 )}$ \\
\hline
\end{tabular}

Panel A. Racial Difference in Net Worth (IHS) and the Explained Portion

$\begin{array}{lllllr}\text { Explained by Control } & 2.43 & 2.67 & 3.18 & 2.53 & 2.75 \\ \text { Variables } & 1.44 & 1.20 & 0.69 & 0.21 & -0.01 \\ \text { Unexplained } & 63 \% & 69 \% & 82 \% & 92 \% & 100 \% \\ \text { SHARE EXPLAINED } & & & & -0.32 \\ \end{array}$

Panel B. Share of Explained Portion Accounted for by:

\begin{tabular}{|c|c|c|c|c|c|c|}
\hline DEMOGRAPHICS & $29 \%$ & $22 \%$ & $14 \%$ & $32 \%$ & $30 \%$ & $25 \%$ \\
\hline -Age & $4 \%$ & $2 \%$ & $-6 \%$ & $28 \%$ & $24 \%$ & $16 \%$ \\
\hline -Nuclear Family Traits & $18 \%$ & $15 \%$ & $16 \%$ & $-4 \%$ & $-1 \%$ & $1 \%$ \\
\hline -Extended Family Profile & $7 \%$ & $5 \%$ & $3 \%$ & $8 \%$ & $7 \%$ & $8 \%$ \\
\hline HUMAN CAPITAL & $29 \%$ & $45 \%$ & $26 \%$ & $27 \%$ & $34 \%$ & $18 \%$ \\
\hline -Education & $4 \%$ & $0 \%$ & $-1 \%$ & $3 \%$ & $-7 \%$ & $-9 \%$ \\
\hline $\begin{array}{l}\text {-Attitudes toward saving \& } \\
\text { investing }\end{array}$ & $9 \%$ & $7 \%$ & $5 \%$ & $10 \%$ & $8 \%$ & $6 \%$ \\
\hline -Occ, Ind, Years FT & $16 \%$ & $9 \%$ & $5 \%$ & $14 \%$ & $9 \%$ & $5 \%$ \\
\hline -Income & & $28 \%$ & $17 \%$ & & $24 \%$ & $16 \%$ \\
\hline HOUSING & $7 \%$ & $7 \%$ & $42 \%$ & $11 \%$ & $12 \%$ & $37 \%$ \\
\hline -Real Estate Trends & $0 \%$ & $0 \%$ & $0 \%$ & $-1 \%$ & $1 \%$ & $-2 \%$ \\
\hline -Housing Tenure & $7 \%$ & $6 \%$ & $1 \%$ & $12 \%$ & $11 \%$ & $3 \%$ \\
\hline -Urban location & $0 \%$ & $0 \%$ & $0 \%$ & $0 \%$ & $0 \%$ & $1 \%$ \\
\hline -Homeownership & & & $40 \%$ & & & $36 \%$ \\
\hline $\begin{array}{l}\text { INHERITANCE AND FAMILY } \\
\text { SUPPORT }\end{array}$ & $26 \%$ & $22 \%$ & $15 \%$ & $25 \%$ & $21 \%$ & $15 \%$ \\
\hline -Inheritance & $7 \%$ & $6 \%$ & $4 \%$ & $9 \%$ & $8 \%$ & $5 \%$ \\
\hline -Family Financial Support & $19 \%$ & $16 \%$ & $11 \%$ & $16 \%$ & $13 \%$ & $10 \%$ \\
\hline HEALTH & $7 \%$ & $4 \%$ & $2 \%$ & $3 \%$ & $2 \%$ & $1 \%$ \\
\hline
\end{tabular}




\section{Table 5: Wealth Differences Using the DiNardo, Fortin, and Lemieux Reweighting Estimator}

This table summarizes the results of a decomposition of the racial wealth gap using the DiNardo, Fortin, and Lemieux (DFL) reweighting estimator applied to the data reported in the Survey of Consumer Finances from 2001 to 2016. The DFL estimator reweights data from one group to make it similar in composition to another. Panel A shows results the of the reweighting at the mean and for various percentiles of net worth distribution for white/black wealth differences, while Panel B shows the results for white/Hispanic wealth differences.

Panel A. White/Black Wealth Differences

\begin{tabular}{|c|c|c|c|c|c|c|c|c|}
\hline & \multicolumn{2}{|c|}{ Observed Net Worth } & \multicolumn{3}{|c|}{ White Net Worth Using Black Weights } & \multicolumn{3}{|c|}{ Observables Explain: } \\
\hline & $\begin{array}{c}\text { Black } \\
\text { Families } \\
\end{array}$ & $\begin{array}{l}\text { White } \\
\text { Families }\end{array}$ & $\begin{array}{l}\text { Reweighting Without } \\
\text { Income or Housing }\end{array}$ & $\begin{array}{l}\text { Reweighting with } \\
\text { Usual Income }\end{array}$ & $\begin{array}{l}\text { Reweighting with Usual } \\
\text { Income and Housing }\end{array}$ & $\begin{array}{l}\text { No Income } \\
\text { or Housing }\end{array}$ & $\begin{array}{c}\text { With } \\
\text { Income }\end{array}$ & $\begin{array}{l}\text { With Income } \\
\text { and Housing }\end{array}$ \\
\hline Mean & 7 & 10.8 & 8.4 & 7.5 & 7.2 & $64 \%$ & $89 \%$ & $95 \%$ \\
\hline $\begin{array}{l}\text { ptile of } \\
\text { wealth } \\
\text { dist. }\end{array}$ & & & & & & & & \\
\hline 10 & -9.3 & 7.7 & -9.0 & -8.8 & -9.3 & $98 \%$ & $97 \%$ & $100 \%$ \\
\hline 25 & 6.7 & 11.0 & 8.9 & 5.2 & 6.2 & $47 \%$ & $134 \%$ & $111 \%$ \\
\hline 50 & 10.5 & 12.7 & 11.5 & 10.9 & 10.6 & $56 \%$ & $81 \%$ & $94 \%$ \\
\hline 75 & 12.2 & 13.8 & 13.0 & 12.8 & 12.7 & $53 \%$ & $67 \%$ & $73 \%$ \\
\hline 90 & 13.2 & 14.8 & 14.0 & 13.8 & 13.8 & $50 \%$ & $61 \%$ & $64 \%$ \\
\hline 95 & 13.8 & 15.4 & 14.6 & 14.5 & 14.4 & $48 \%$ & $57 \%$ & $60 \%$ \\
\hline
\end{tabular}

Panel B. White/Hispanic Wealth Differences

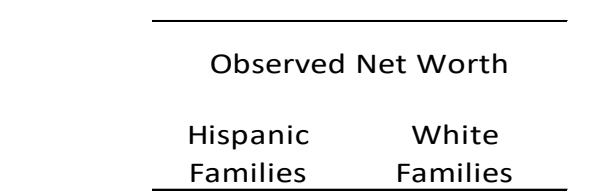

Mean

10.8
White Net Worth Using Hispanic Weights \begin{tabular}{ccc}
$\begin{array}{c}\text { Reweighting Without } \\
\text { Income or Housing }\end{array}$ & $\begin{array}{c}\text { Reweighting with } \\
\text { Usual Income }\end{array}$ & $\begin{array}{c}\text { Reweighting with Usual } \\
\text { Income and Housing }\end{array}$ \\
\hline
\end{tabular}
7.6 Income and Housing
Observables Explain:

\begin{tabular}{ccc}
$\begin{array}{c}\text { No Income } \\
\text { or Housing }\end{array}$ & With & With Income \\
Income & and Housing \\
\hline
\end{tabular}

$121 \%$

$128 \%$

ptile of

wealth

dist.

$\begin{array}{lcc}10 & -7.4 & 7.7 \\ 25 & 8.6 & 11.0 \\ 50 & 10.5 & 12.7 \\ 75 & 12.3 & 13.8 \\ 90 & 13.3 & 14.8 \\ 95 & 13.9 & 15.4\end{array}$

-8.7
8.4
11.0
12.6
13.7
14.4

-8.8
7.5
10.7
12.5
13.6
14.2

-9.0
7.0
10.5
12.4
13.6
14.2

$\begin{array}{ccc}109 \% & 110 \% & 111 \% \\ 108 \% & 146 \% & 166 \% \\ 79 \% & 90 \% & 100 \% \\ 76 \% & 84 \% & 89 \% \\ 74 \% & 80 \% & 83 \% \\ 71 \% & 78 \% & 80 \%\end{array}$




\section{Table 6: Allocation of Contributions to the Racial Wealth Gap Using DFL Reweighting Estimator}

This table shows the separate contributions to the nonwhite/white wealth gaps of groups of controls used in the DFL nonparametric reweighting decomposition using SCF data for 2001 to 2016. The specification reported is from Table 5 and uses all control variables including income, but excludes home ownership. Panel A shows the contributions of factors to the white/black wealth gap across the wealth distribution. Panel B shows the contributions of factors to the white/Hispanic wealth gap across the wealth distribution.

Panel A. White/Black

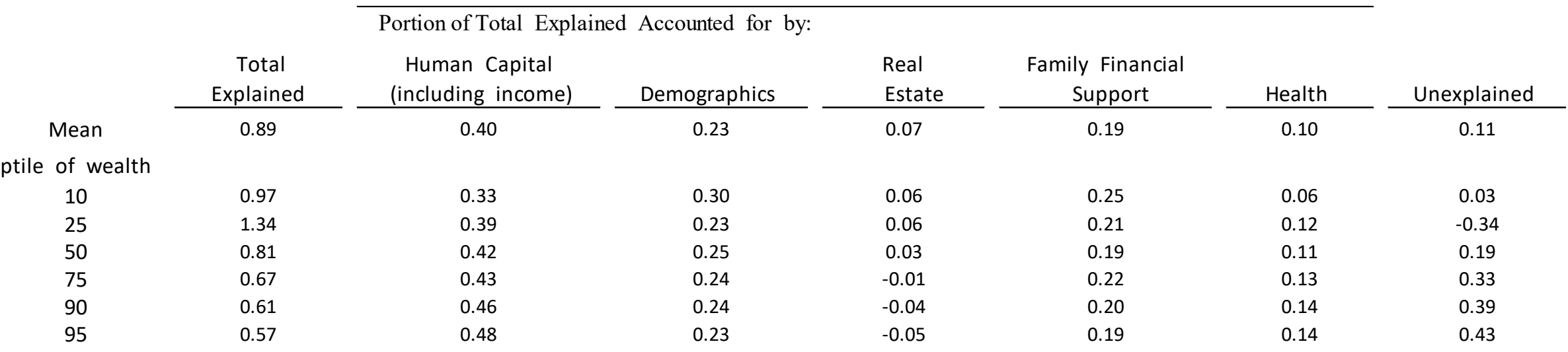

Panel B. White/Hispanic

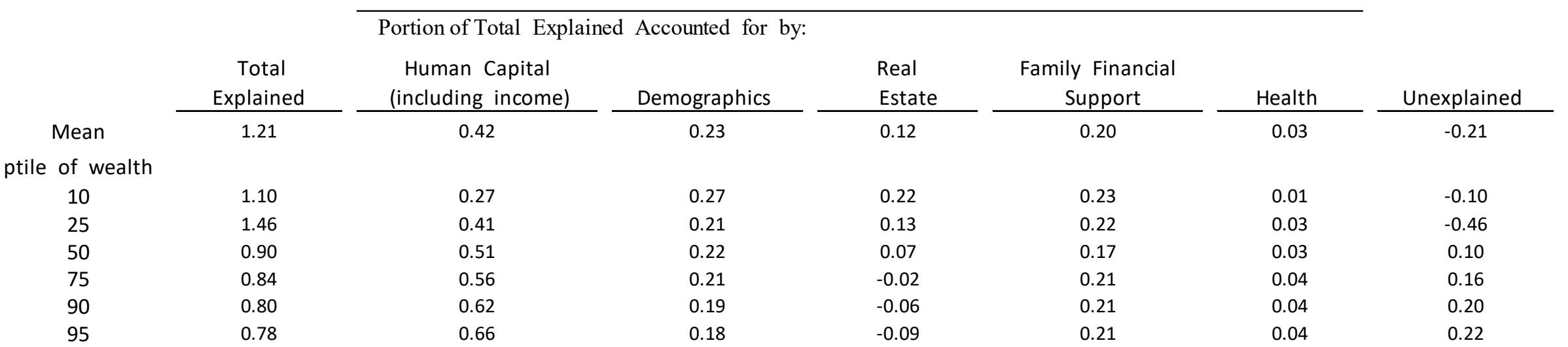


Figure A1. 2016 Distributions of Net Worth and Normal Income by Racial Group

A1.a. Kernel Density of Net Worth (IHS) for White(1), Black(2), and Hispanic(3) Families

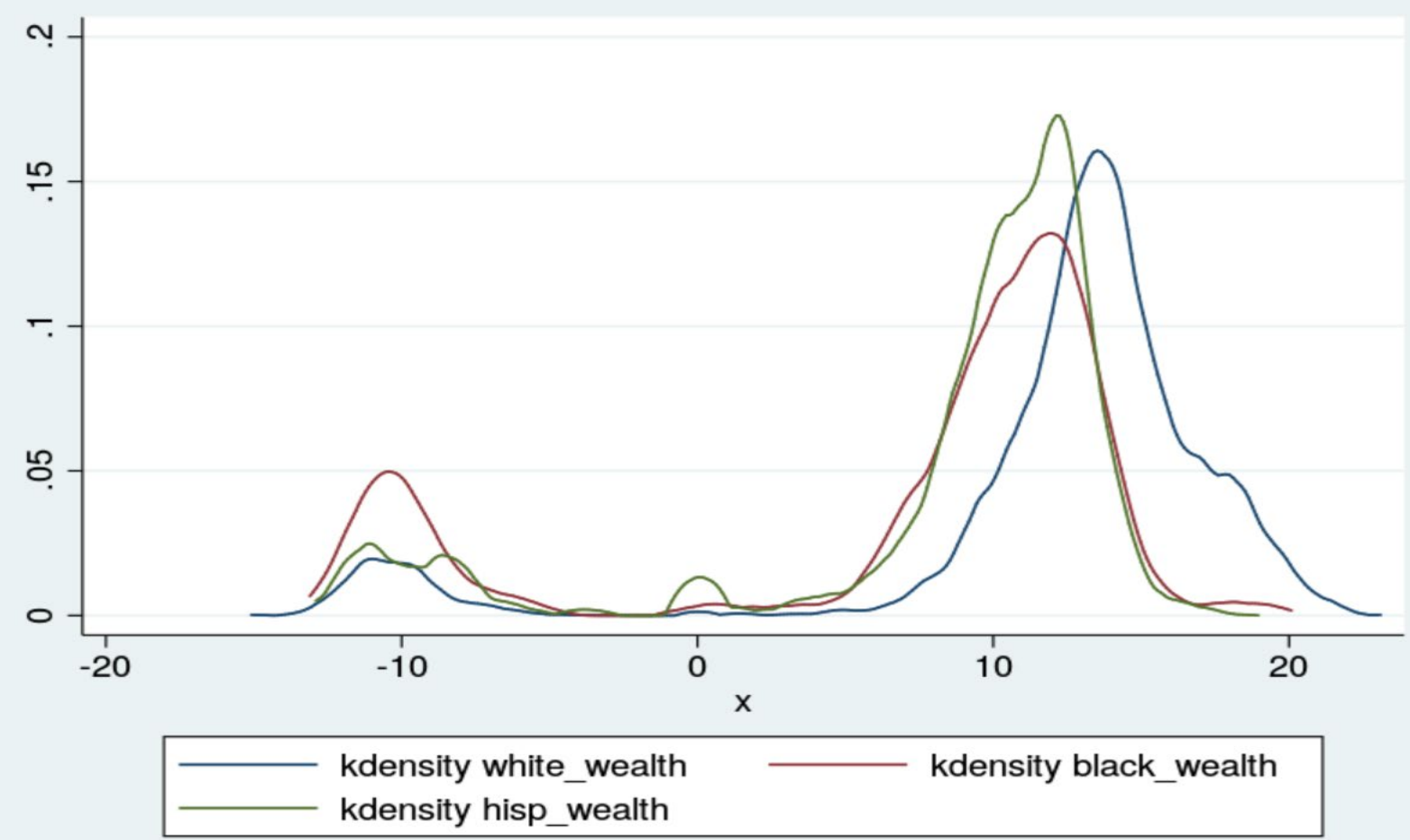

A1.b. Kernel Density of Normal Income (IHS) for White(1), Black(2), and Hispanic(3) Families

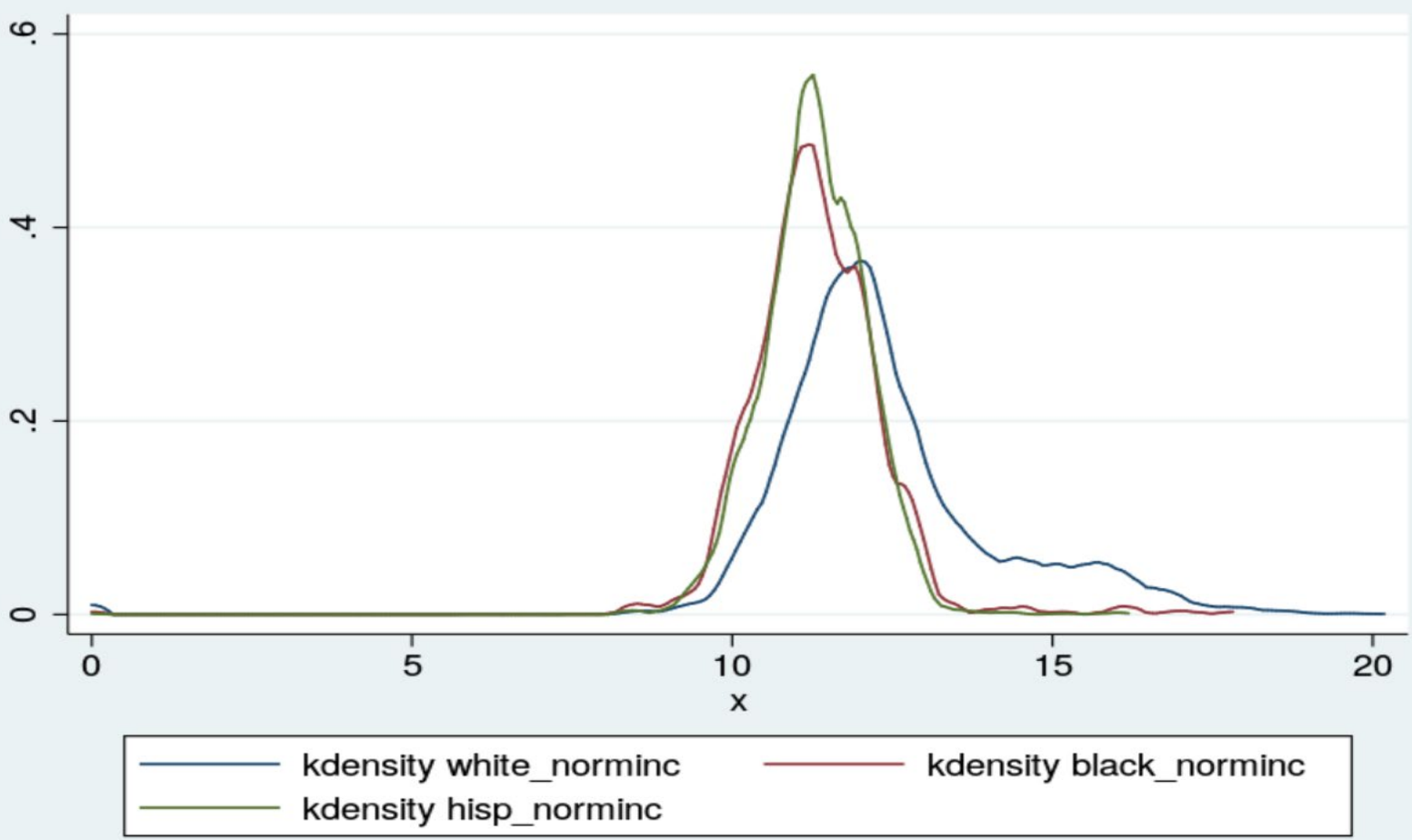

Source: Authors' analysis of 2016 SCF. 


\section{Appendix Table 1. Full Results from OLS Wealth Regression Including All Controls (Table 3, Panel A, Column 2)}

This table summarizes the results from an OLS regressions using data from the Survey of Consumer Finances for 2001 to 2016 with the inverse hyperbolic sine (IHS) of family net worth as the dependent variable. The coefficients for each control variable, with excluded exceptions listed below, along with a standard error (in parentheses) is given. Black families are the omitted group for race. The covariates not shown (for space) include year fixed effects, occupation, industry, and numbers of sibling for both the respondent (R) and spouse (SP), as well as educational attainment, health, and parental longevity for the spouse. Each of those latter coefficients, however, are shown for the respondent. *, **, and *** indicate significance at the 10 percent, 5 percent, and 1 percent levels, respectively.

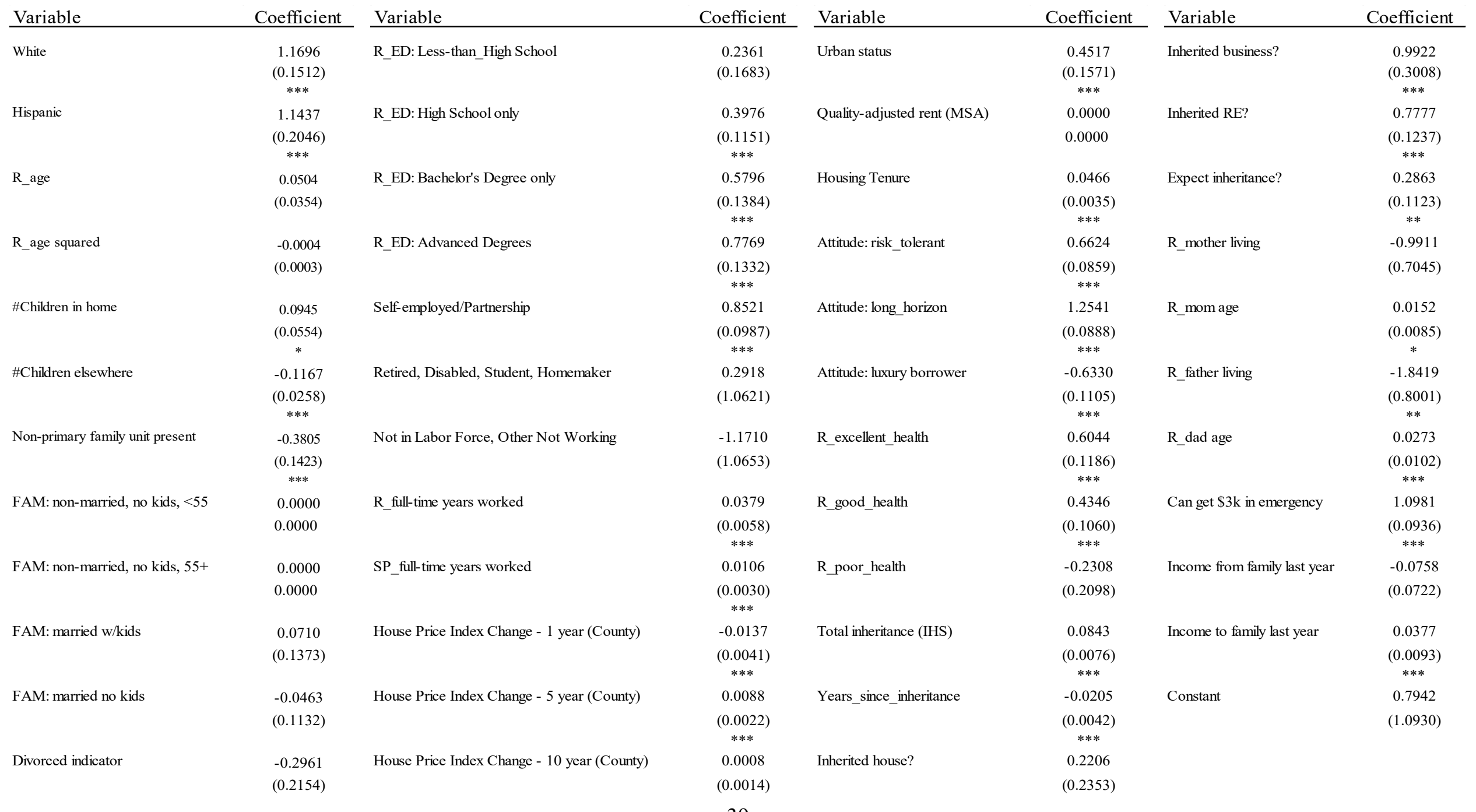

